\title{
South Asia river-flow projections and their implications for water resources
}

\author{
C. Mathison ${ }^{1}$, A. J. Wiltshire ${ }^{1}$, P. Falloon ${ }^{1}$, and A. J. Challinor ${ }^{2}$ \\ ${ }^{1}$ Met Office Hadley Centre, Fitzroy Road, Exeter, EX1 3PB, UK \\ ${ }^{2}$ School of Earth and Environment, Institute for Climate and Atmospheric Science, University of Leeds, Leeds, LS2 9AT, UK \\ Correspondence to: C. Mathison (camilla.mathison@metoffice.gov.uk)
}

Received: 16 April 2015 - Published in Hydrol. Earth Syst. Sci. Discuss.: 16 June 2015

Revised: 5 November 2015 - Accepted: 9 November 2015 - Published: 7 December 2015

\begin{abstract}
South Asia is a region with a large and rising population, a high dependence on water intense industries, such as agriculture and a highly variable climate. In recent years, fears over the changing Asian summer monsoon (ASM) and rapidly retreating glaciers together with increasing demands for water resources have caused concern over the reliability of water resources and the potential impact on intensely irrigated crops in this region. Despite these concerns, there is a lack of climate simulations with a high enough resolution to capture the complex orography, and water resource analysis is limited by a lack of observations of the water cycle for the region. In this paper we present the first $25 \mathrm{~km}$ resolution regional climate projections of river flow for the South Asia region. Two global climate models (GCMs), which represent the ASM reasonably well are downscaled (1960-2100) using a regional climate model (RCM). In the absence of robust observations, ERA-Interim reanalysis is also downscaled providing a constrained estimate of the water balance for the region for comparison against the GCMs (1990-2006). The $\mathrm{RCM}$ river flow is routed using a river-routing model to allow analysis of present-day and future river flows through comparison with available river gauge observations. We examine how useful these simulations are for understanding potential changes in water resources for the South Asia region. In general the downscaled GCMs capture the seasonality of the river flows but overestimate the maximum river flows compared to the observations probably due to a positive rainfall bias and a lack of abstraction in the model. The simulations suggest an increasing trend in annual mean river flows for some of the river gauges in this analysis, in some cases almost doubling by the end of the century. The future maximum river-flow rates still occur during the ASM period, with
\end{abstract}

a magnitude in some cases, greater than the present-day natural variability. Increases in river flow could mean additional water resources for irrigation, the largest usage of water in this region, but has implications in terms of inundation risk. These projected increases could be more than countered by changes in demand due to depleted groundwater, increases in domestic use or expansion of water intense industries. Including missing hydrological processes in the model would make these projections more robust but could also change the sign of the projections.

\section{Introduction}

South Asia, the Indo-Gangetic Plain in particular, is a region of rapid socio-economic change where both population growth and climate change is expected to have a large impact on available water resources and food security. The region is home to almost 1.6 billion people and the population is forecast to increase to more than 2 billion by 2050 (United Nations, 2013). The economy of this region is rural and highly dependant on climate sensitive sectors such as the agricultural and horticultural industry, characterised by a large demand for water resources. As a result, over the coming decades, the demand for water from all sectors; domestic, agricultural and industrial is likely to increase (Gupta and Deshpande, 2004; Kumar et al., 2005).

The climate of South Asia is dominated by the Asian summer monsoon (ASM), with much of the water resources across the region provided by this climatological phenomena during the months of June-September (Goswami and Xavier, 2005). The contribution from glacial melt to water 
resources is less certain but likely to be important outside the ASM period during periods of low river flow (Mathison et al., 2013). Glaciers and seasonal snowpacks are natural hydrological buffers releasing water during the drier periods, such as spring and autumn, when the flows of some catchments in this region are at their lowest. Similarly they may act to buffer inter-annual variability as well releasing water during warmer drier years and accumulating during wetter colder years (Barnett et al., 2005). However, Kaser et al. (2010) showed that the influence of glacial melt reduces with distance downstream, as other influences such as evaporation and precipitation increase in importance. Immerzeel et al. (2010) found that by the 2050s, the main upstream water supply could decrease due to a reduction in snow and glacial melt (reductions of $8 \%$ for the upper Indus and more than $18 \%$ for the Ganges and Brahmaputra). Meltwater plays an important role for the Indus and Brahmaputra particularly, accounting for a larger percentage of the downstream flow than the Ganges (where meltwater is approximately $10 \%$ of the downstream flow). However, Immerzeel et al. (2010) also showed that these reductions in meltwater are offset by an increase in precipitation in all three basins. Immerzeel et al. (2010) used coarse-resolution general circulation models (GCMs) known to have difficulties in capturing monsoon precipitation and in estimating the relationship between daily mean temperature and melting of snow and ice.

Recent studies have highlighted uncertainty in both glacier mass balance and ASM rainfall. Fujita and Nuimura (2011) showed a negative mass balance for three benchmark glaciers in the Nepal Himalayas. Bolch et al. (2012) and Gardelle et al. (2013) highlighted losses more generally from western, eastern and central Himalayan glaciers. These observed changes in Himalayan glaciers can be attributed to the increase in temperature already experienced across the region, with warming more pronounced at higher elevations and during winter months (Shrestha and Aryal, 2011). There are however some glaciers in the Karakoram region showing increases in mass, which has been attributed to a decrease in temperature for this region (Bolch et al., 2012; Gardelle et al., 2013). Projections of future glacial change are challenging due to poor understanding of glacial processes, diversity in climate extremes and the complex orography of the region (Bolch et al., 2012). Complex orography contributes to other processes such as avalanching and therefore debris cover. The relationship between debris cover and melt is complex with a wide variety of responses across different glaciers across the Himalayan arc (Gardelle et al., 2013). The thickness of debris cover is widely thought to significantly affect the response of the glacier to climate, with thick debris cover tending to slow down surface melting (Bolch et al., 2012; Scherler et al., 2011). However, on the regional scale Kääb et al. (2012) found, using satellite data, similar thinning rates between clean and debris covered ice despite insulation by debris cover at some sites. Kääb et al. (2012) suggested that the insulating effect of debris layers with thicknesses exceed- ing a few centimetres depends on the continuity of the coverage. Therefore, changes in the thickness of debris across a glacier could change the melt rate on a local scale even across a single glacier tongue.

The ASM is also uncertain, Christensen et al. (2007) highlighted two climate features that could influence the ASM, including a general weakening of monsoonal flows while enhanced moisture convergence could increase precipitation. Any reduction in water availability from either resource is likely to put more pressure on groundwater resources, which is not sustainable in the longer term (Rodell et al., 2009). There is some disagreement in the literature regarding the main effects of climate change on this region. Gregory et al. (2005) suggested that the availability and quality of groundwater for irrigation could be more important factors influencing food security than the direct effects of climate change, particularly for India. However, Aggarwal et al. (2012) suggested that an increase in extremes (both temperature and precipitation) could lead to instability in food production and it is this variability in food production that is potentially the most significant effect of climate change for the South Asia region.

Despite the general uncertainty in the reliability of water resources and the impacts of climate change for this region, there are few simulations available with a high enough resolution for capturing the complex topography of the Himalayan region. The water balance for the South Asia region as a whole is generally poorly understood with limited observing networks and data availability for both precipitation and river flows presenting a real challenge for validating models and estimates of water balance. This analysis seeks to use regional climate simulations to develop our understanding of the water cycle for the region in the context of the complete climate system, while acknowledging that more needs to be done to address the missing hydrological processes in the model. Regional climate model (RCM) simulations are a widely used method across climate science for downscaling GCMs, including the regional IPCC assessment but are used in many other regional climate projects (Christensen et al., 2007; Murphy et al., 2009; Jacob et al., 2007). RCMs are based on the same physical equations as GCMs and therefore represent the entire climate system including the carbon and water cycle. Though there are some limitations due to missing processes, their higher resolution allows a better representation of the regional-scale processes; especially in regions of complex topography such as the Himalayas (Lucas-Picher et al., 2011). RCMs are designed to maintain the conservation of water, mass, energy and momentum, essential for analysis on climate timescales. LucasPicher et al. (2011) conducted a comprehensive assessment of four RCMs run over South Asia demonstrating their ability to capture the monsoon; this analysis includes the RCM used here. Mathison et al. (2013) compared GCM and RCM outputs for temperature and precipitation specifically for the RCM used in this analysis. 
Perhaps due to the lack of adequate resolution regional climate simulations available for this region, there are relatively few studies that consider the value of downscaling using RCMs for hydrological applications for this region. However, Akhtar et al. (2008) found that RCM data produced better results when used with a hydrological model than using poor-quality observation data; this implies greater confidence in the RCM simulated meteorology than available observational data for this region (Wiltshire, 2014). Therefore, in the literature hydrological analysis is typically at the global scale using GCMs coupled with hydrological models (Milly et al., 2005; Hirabayashi et al., 2008; Falloon et al., 2011; Wiltshire et al., 2013a, b) or at the basin scale using standalone hydrological models (Singh and Kumar, 1997; Singh and Bengtsson, 2005; Singh et al., 2008; Seidel et al., 2000) such as the soil water assessment tool (SWAT; Arnold et al., 1998). Weather data in SWAT are either simulated within the model using a weather generator or taken from observations of daily precipitation and maximum/minimum temperature (Nyeko, 2015). This approach may be appropriate for small domains within which there is consistency in rainfall patterns but may not be suitable for large domains in South Asia due to the high temporal and spatial variability in precipitation across the region (Hijioka et al., 2014). Gosain et al. (2006) used the SWAT model with $50 \mathrm{~km}$ resolution daily RCM weather data to conduct a climate change impact assessment of the hydrology of several individual basins over India for two 20-year periods representing the present day (1981-2000) and future (2041-2060). Gosain et al. (2006) compared the differences between the two periods, rather than focussing on absolute values, to find that climate change causes an increase in precipitation, river flow and evaporation for the Ganges basin. High variability across basins and subbasins means that parts of the Ganges basin could experience seasonal or regular water-stressed conditions under climate change (Gosain et al., 2006), although it is not exactly clear which climate change scenario has been used for these simulations. There are more examples of the application of RCMs for hydrological analysis for other regions such as the UK and Europe. Kay et al. (2006) used $25 \mathrm{~km} \mathrm{RCM} \mathrm{data} \mathrm{in} \mathrm{a}$ catchment-based rainfall-runoff model to estimate the flood frequency of small UK river basins to good effect. Dankers et al. (2007) used an RCM to evaluate the benefits of using high spatial resolution climate information for the Danube basin. Sampson et al. (2014) have also demonstrated the importance of the resolution of precipitation data for a region of Ireland for hydrological impact modelling.

The typical domain and resolution of RCM simulations enables the analysis of areas spanning multiple river basins covering a larger area than is usually possible with hydrological models. This means that there is consistent forcing across different basins. The use of the RCM generated runoff within the hydrological model also preserves the consistency of the projections with atmospheric forcing, which is not possible if the runoff is derived within a hydrological model.
However, there are few regional river-flow analyses currently available, where these consistencies are maintained. Biemans et al. (2013) analysed the RCM projections used in this analysis in terms of water availability for food production for selected river basins using a coupled hydrology and dynamic vegetation model; however, so far no specific analysis of river flows has been done for these RCMs. Therefore, we present the first $25 \mathrm{~km}$ resolution regional climate projections of river flow for the South Asia region by using RCM generated runoff within a routing model to estimate river flow thereby enabling consistency to be maintained across basins and with the driving climate scenario. This is a new application of the highest resolution RCM data currently available for this region, to enable analysis of the impacts of climate on river flows in conjunction with the strategic sampling of climate variability from selected GCMs. We use a novel approach to the consideration of variability of river flows through analysis of the upper and lower parts of the distribution, in addition to the mean flows.

The aim of this analysis is to examine how useful RCM simulations are for understanding how river flows could change in South Asia in the future. Irrigation is an important part of the agricultural industry for this part of the world, with the Indo-Gangetic Plain traditionally providing the staple crops of rice and wheat (Aggarwal et al., 2000) for India and South Asia as a whole; the continued success of these crops is therefore important for the food and water security of the region. We discuss the potential implications of projected changes in the water resources needed to maintain yields of these crops in a changing climate. The models, observations and the analysis used are described in Sect. 2, while a brief evaluation of the driving data and the river flow analysis is presented in Sect. 3. The implications of the potential changes in river flows on water resources and conclusions are discussed in Sects. 4 and 5, respectively.

\section{Methodology}

\subsection{Models}

Figure 1 summarises the methodology described in this section in a flow chart, highlighting the main stages in the generation of the presented river-flow projections and the approximate resolution of the model data used.

\subsubsection{GCM and RCM forcing}

This analysis utilizes $25 \mathrm{~km}$ resolution regional climate modelling of the Indian sub-continent to provide simulations across the Hindu-Kush Karakoram Himalaya mountain belt. These RCM simulations form part of the ensemble produced for the EU-HighNoon project (referred to hereafter as $\mathrm{HN}$ RCMs), for the whole of the Indian subcontinent $\left(25^{\circ} \mathrm{N}\right.$, $79^{\circ} \mathrm{E}-32^{\circ} \mathrm{N}, 88^{\circ} \mathrm{E}$ ), for the period $1960-2100$. The other simulations in the HighNoon ensemble, which used another 


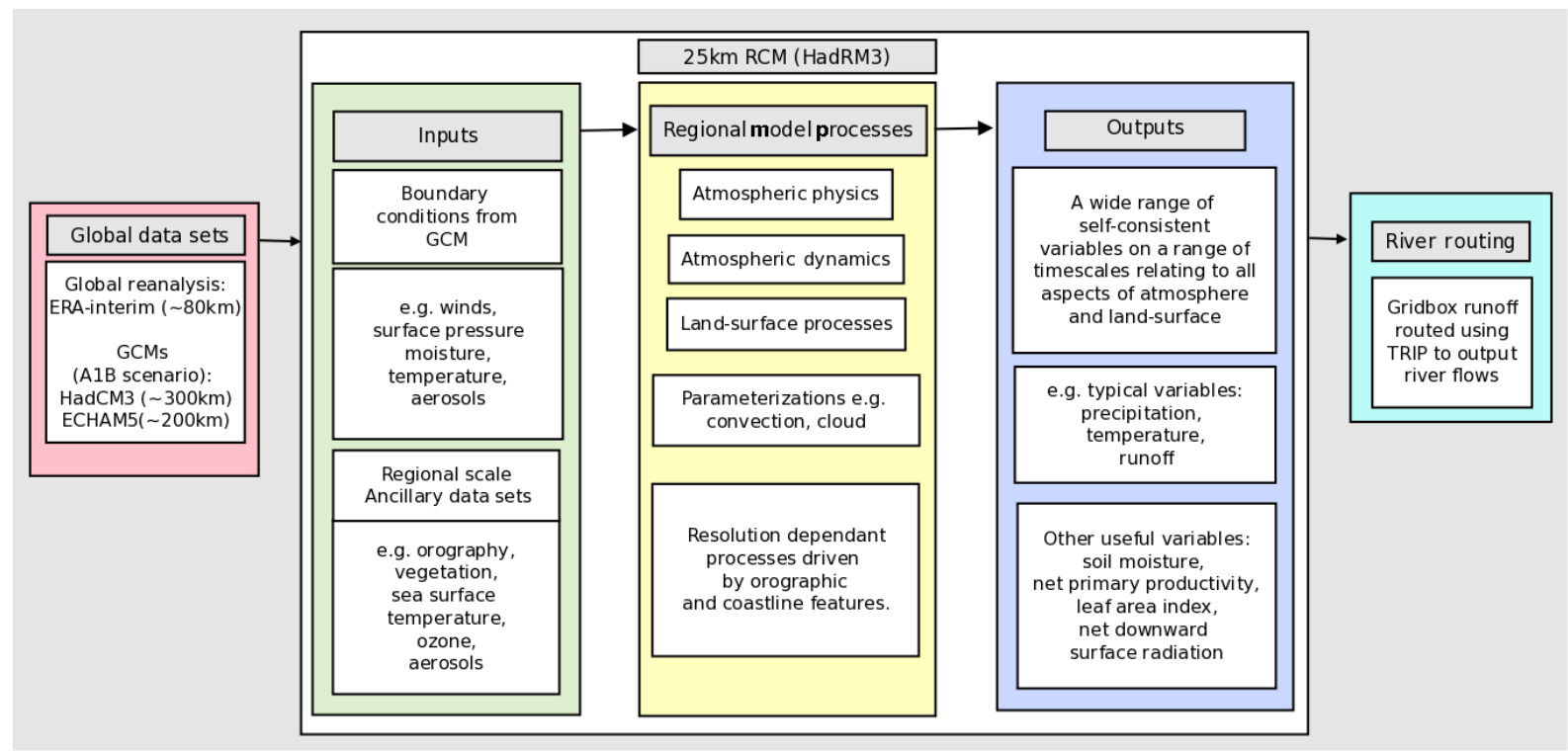

Figure 1. A flow chart showing the methodology for the presented analysis.

RCM, the Regional Model from the Max Planck Institute for Meteorology (REMO; Jacob et al., 2007), were unavailable for use in this analysis. Therefore, one RCM, the Hadley Centre Regional Climate Model (HadRM3) RCM (Jones et al., 2004) is used to generate the river-flow projections presented here. While the additional RCM would be useful here, analysis of the ERA-Interim driven HadRM3 and REMO simulations over the western Himalayas by Dimri et al. (2013) show that both models run at $25 \mathrm{~km}$ resolution over comparable domains have similar distributions of precipitation, temperature and inter-annual variability, despite having different representations of orography. Analysis of the complete HighNoon ensemble for the GangesBrahmaputra basin in Mathison et al. (2013) also indicates a small spread between HNRCMs for the 30-year mean climatologies of temperature. Precipitation is more variable for this basin, with a larger spread between HNRCMs. However, the RCM uncertainty defined by these two models (REMO and HadRM3) is still smaller than the climate uncertainty represented by the selected GCMs with the influence of the GCM on the projections of precipitation as great as the variability between RCMs (Kumar et al., 2013). Therefore, the most important contribution to the input uncertainty is from the GCM (Akhtar et al., 2008) and using two GCMs to provide boundary data to one RCM provides a better estimate of climate uncertainty than using a single GCM to drive two RCMs, which would be the computational equivalent. On this basis we use HadRM3 driven by two carefully selected GCMs for this analysis. However, other RCMs, not yet applied to this region could produce different projections.

In order to sample climate uncertainty, we use two GCM simulations that have been shown to capture a range of temperatures and variability in precipitation similar to the AR4 ensemble for Asia (Christensen et al., 2007). Although using just two ensemble members is unlikely to capture the full range of uncertainty of a larger ensemble, the two models used for these simulations have been shown to capture the main features of the large-scale circulation (particularly the ASM) (Kumar et al., 2013; Annamalai et al., 2007; Mathison et al., 2013), which is not true of all GCMs. The experimental design of the HighNoon ensemble compromises between the need for higher-resolution climate information for the region and the need for a number of ensemble members to provide a range of uncertainty. The length of the simulations needed and the limited number of GCMs that are able to simulate the ASM also affect the number of ensemble members. These factors are all important given the limited computational resources available. The GCMs are the following: the third version of the Met Office Hadley Centre Climate Model (HadCM3; Pope et al., 2000; Gordon et al., 2000, a version of the Met Office Unified Model) and ECHAM5 (third realization; Roeckner et al., 2003) are downscaled using the HadRM3 RCM (Jones et al., 2004). These two GCMs capture the uncertainty in the sign of the projected change in precipitation with one showing an increase (HadCM3) and the other a decrease (ECHAM5). This feature is a key reason for the selection of these two GCMs. In addition to the GCMs, ERA-Interim data (Simmons et al., 2007; Dee et al., 2011) are also downscaled using the HadRM3 RCM. ERA-Interim is a reanalysis product that combines model and observations to provide a constrained estimate of the water balance of the region. The ERA-Interim (also referred to as ERAint) simulation has also been shown to capture the role of steep topography on moisture transport fluxes and vertical flow for the western Himalayas (Dimri et al., 2013). Therefore, for this region, where there is a lack of robust observations, particu- 
larly of the water cycle (see Sects. 2.3.1 and 3.1), it provides a useful benchmark against which to compare the GCM driven simulations. A similar approach is described in a previous study by Wiltshire (2014).

These RCM simulations are currently the finest resolution climate modelling available for this region (Mathison et al., 2013; Moors et al., 2011; Kumar et al., 2013). HadRM3 has 19 atmospheric levels and the lateral atmospheric boundary conditions are updated 3 hourly and interpolated to a $150 \mathrm{~s}$ time step. These simulations include a detailed representation of the land surface in the form of version 2.2 of the Met Office Surface Exchange Scheme (MOSESv2.2; Essery et al., 2003), which includes a full physical energy-balance snow model (Lucas-Picher et al., 2011). MOSESv2.2 treats subgrid land cover heterogeneity explicitly with separate surface temperatures, radiative fluxes (long wave and shortwave), heat fluxes (sensible, latent and ground), canopy moisture contents, snow masses and snowmelt rates computed for each surface type in a grid box (Essery et al., 2001). However, the air temperature, humidity and wind speed above the surface are treated as homogenous across the grid box and precipitation is applied uniformly over the different surface types of each grid box. The relationship between the precipitation and the generation of runoff is complicated, depending on not only the intensity, duration and distribution of the rainfall but also the characteristics of the surface. The infiltration capacity of the soil, the vegetation cover, steepness of the orography within the catchment and the size of the catchment are important influencing factors on runoff generation (Linsley et al., 1982). In GCMs and even $25 \mathrm{~km} \mathrm{RCMs} \mathrm{such} \mathrm{as} \mathrm{the} \mathrm{one} \mathrm{presented} \mathrm{here,} \mathrm{the} \mathrm{resolution}$ is often too coarse to explicitly model the large variations of soil moisture and runoff within a catchment and therefore the major processes are parameterized (Gedney and Cox, 2003). The method used within MOSES2.2 for generating surface and subsurface runoff across a grid box is through partitioning the precipitation into interception by vegetation canopies, throughfall, runoff and infiltration for each surface type (Essery et al., 2003). The Dolman and Gregory (1992) infiltration excess mechanism generates surface runoff; this assumes an exponential distribution of point rainfall rate across the fraction of the catchment where it is raining (Clark and Gedney, 2008). Moisture fluxes are allowed between soil layers; these are calculated using the Darcy equation, with the water going into the top layer defined by the grid-box average and any excess removed by lateral flow (Essery et al., 2001). Excess moisture in the bottom soil layer drains from the bottom of the soil column at a rate equal to the hydraulic conductivity of the bottom layer as subsurface runoff (Clark and Gedney, 2008). The performance of MOSESv2.2 is discussed in the context of a GCM in Essery et al. (2001); however, no formal assessment of MOSESv2.2 and the runoff generation in particular has been done for the RCM.

\subsubsection{River-routing model}

In this analysis the simulated $25 \mathrm{~km}$ grid-box runoff is converted into river flow using the $0.5^{\circ}$ Total Runoff Integrating Pathways river-routing scheme (TRIP; Oki and Sud, 1998) as a post-processing step. TRIP is a simple model that moves water along a pre-defined $0.5^{\circ}$ river network; the Simulated Topological Network at $30 \mathrm{~min}$ resolution (STN-30p, version 6.01; Vörösmarty et al., 2000a, b; Fekete et al., 2001) in order to provide mean runoff per unit area of the basin; this can be compared directly with river gauge observations. TRIP was previously used in Falloon et al. (2011), which used GCM outputs directly to assess the skill of a global river-routing scheme. The TRIP model has been shown to agree well with observed river-flow gauge data (Oki et al., 1999) and largely showed good skill when comparing runoff from several land-surface models (Morse et al., 2009). Implementation of TRIP in two GCMs, HadCM3 and HadGEM1, is described by Falloon et al. (2007) and was found to improve the seasonality of the river flows into the ocean for most of the major rivers. Using TRIP ensures the river-flow forcing is consistent with the atmospheric forcing; however, it also assumes that all runoff is routed to the river network and as such there is no net aquifer recharge/discharge. This may not be the case in regions with significant groundwater extraction, which is subsequently lost though evaporation and transported out of the basin. These simulations do not include representation of extraction, reservoirs or dams. Many of the river gauges used in this analysis and described in Sect. 2.2 are located at large dams along rivers in these basins, and therefore the comparison between the simulations and the river gauges could be affected by these large features. Extraction, particularly for irrigation purposes, is large in this region (Biemans et al., 2013); this means that the extraction-evaporation, as well as subsequent recycling, of water in a catchment (Harding et al., 2013; Tuinenburg et al., 2014) is not considered in this analysis. The routed runoff of the HNRCM simulations are generally referred to hereafter using only the global driving data abbreviations: ERAint, ECHAM5 and HadCM3 (except Sect. 3.1 where we refer to the HadCM3 GCM and ERAint data sets before downscaling).

\subsubsection{Emission scenario}

These simulations use the Special Report on Emissions Scenarios (SRES) A1B scenario (Nakicenovic et al., 2000). The SRES scenarios were devised according to the production of greenhouse gases and aerosol precursor emissions as part of the AR4 IPCC report (Christensen et al., 2007). The A1 storyline and scenario family represents a future world of very rapid economic growth, global population that peaks in mid-century and declines thereafter, and rapid introduction of new and more efficient technologies. The A1B scenario specifically, represents this future world where there is bal- 


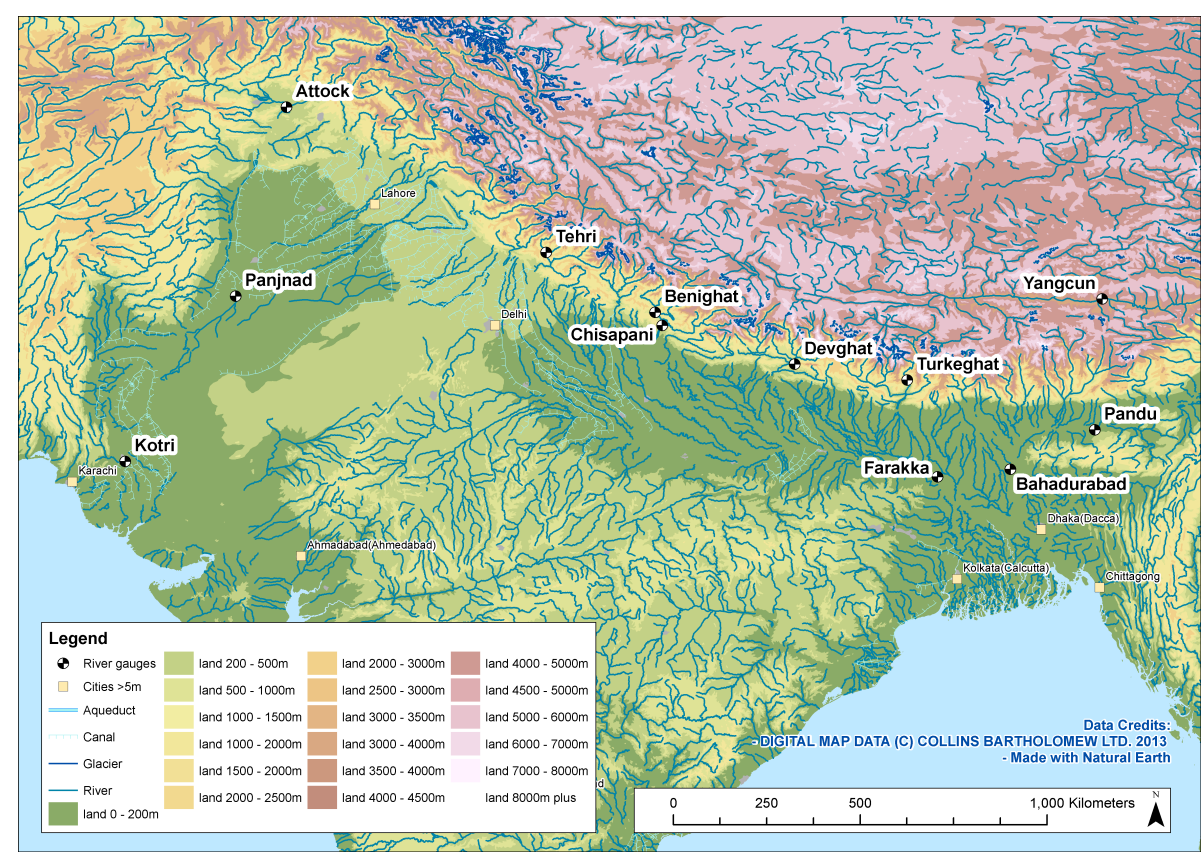

Figure 2. A map showing the locations of the river gauges used in this analysis.

ance across energy sources, i.e. a mixture of fossil and nonfossil fuels (Nakicenovic et al., 2000). This scenario does not represent changes in land use, which remains fixed through the duration of these simulations. This is useful for understanding the effect of climate change in the absence of any adaptation.

\subsection{Observations}

This analysis uses observations of precipitation and river flow to assess the present-day RCM hydrology. The precipitation observations are from the Asian Precipitation - Highly Resolved Observational Data Integration Towards the Evaluation of Water Resources (APHRODITE; Yatagai et al., 2012) data set. APHRODITE is a daily, $0.25^{\circ}$ resolution gridded data set.

The river-flow analysis focusses on a selection of river gauges from the Global Runoff Data Centre (GRDC, 2014) that are located within the three major river basins of South Asia: the Indus and the Ganges-Brahmaputra. These gauges provide observations that are used, in addition to downscaled ERA-Interim river flows, to evaluate the downscaled GCM river flows. The selection of these river gauges aims to illustrate from the perspective of river flows, as modelled in an RCM, that the influence of the ASM on precipitation totals increases, from west to east and north to south across the Himalayan mountain range, while that of western disturbances reduces (Wiltshire, 2014; Dimri et al., 2013; Ridley et al., 2013; Collins et al., 2013). The differing influences across the Himalayan arc result in complex regional differences in sensitivity to climate change, with western re- gions dominated by non-monsoonal winter precipitation and therefore potentially less susceptible to reductions in annual snowfall (Wiltshire, 2014; Kapnick et al., 2014). A brief geographical description of the rivers and the chosen gauges is given in this section, their locations are shown in Fig. 2 and listed in Table 1 (including the abbreviations shown in Fig. 2 and the gauge location in terms of latitude and longitude).

The Indus, originates at an elevation of more than $5000 \mathrm{~m}$ in western Tibet on the northern slopes of the Himalayas, flowing through the mountainous regions of India and Pakistan to the west of the Himalayas. The upper part of the Indus basin is greatly influenced by western disturbances, which contribute late winter snowfall to the largest glaciers and snow fields outside the polar regions; the meltwater from these have a crucial role in defining the water resources of the Indus basin (Wescoat Jr., 1991). In this analysis the Attock gauge is the furthest upstream and the Kotri gauge, located further downstream, provide observations on the main trunk of the Indus River. The Chenab River, located in the Panjnad basin and in this analysis represented by the Panjnad gauge, is a major eastern tributary of the Indus, originating in the Indian state of Himachal Pradesh. In the upper parts of the Chenab sub-basin western disturbances contribute considerably to precipitation, while the foothills are also influenced by the ASM (Wescoat Jr., 1991).

The Ganges River originates on southern slopes of the Himalayas (Thenkabail et al., 2005) and traverses thousands of kilometres before joining with the Brahmaputra in Bangladesh and emptying into the Bay of Bengal (Mirza et al., 1998). The Ganges basin has a population density 10 times the global average making it the most populated 
Table 1. Table listing the rivers and gauges (including their location) used in this analysis; all the observations shown here are from GRDC. The abbreviations used in Fig. 2 are given in column one. The years of data column includes the number of years that data is available since 1950 with "c" to denote where data are continuous and "u" to show where the data are available for that number of years but not as a continuous data set.

\begin{tabular}{llllll}
\hline $\begin{array}{l}\text { Map } \\
\text { abbreviation }\end{array}$ & River name & Gauge name & Latitude & Longitude & Years of data \\
\hline IND_KOT & Indus & Kotri & 25.37 & 68.37 & $14 \mathrm{u}(1950-1978)$ \\
IND_ATT & Indus & Attock & 33.9 & 72.25 & $6 \mathrm{c}(1973-1979)$ \\
CHE_PAN & Chenab & Panjnad & 29.35 & 71.03 & $6 \mathrm{c}(1973-1979)$ \\
BHA_TEH & Bhagirathi & Tehri dam & 30.4 & 78.5 & $3 \mathrm{c}(2001-2004)$ \\
KAR_BEN & Karnali River & Benighat & 28.96 & 81.12 & $25 \mathrm{u}(1963-1993)$ \\
KAR_CHI & Karnali River & Chisapani & 28.64 & 81.29 & $31 \mathrm{c}(1962-1993)$ \\
NAR_DEV & Narayani & Devghat & 27.71 & 84.43 & $23 \mathrm{u}(1963-1993)$ \\
ARU_TUR & Arun & Turkeghat & 27.33 & 87.19 & $10 \mathrm{c}(1976-1986)$ \\
GAN_FAR & Ganges & Farakka & 25.0 & 87.92 & $18 \mathrm{u}(1950-1973)$ \\
BRA_BAH & Brahmaputra & Bahadurabad & 25.18 & 89.67 & $12 \mathrm{u}(1969-1992)$ \\
BRA_YAN & Brahmaputra & Yangcun & 29.28 & 91.88 & $21 \mathrm{u}(1956-1982)$ \\
BRA_PAN & Brahmaputra & Pandu & 26.13 & 91.7 & $13 \mathrm{u}(1956-1979)$ \\
\hline
\end{tabular}

river basin in the world (Johnston and Smakhtin, 2014), it covers 1.09 million $\mathrm{km}^{2}$ with $79 \%$ in India, $13 \%$ in Nepal, $4 \%$ in Bangladesh and $4 \%$ in China (Harding et al., 2013). The main trunk of the Ganges is represented in this analysis by the gauge at the Farakka Barrage, located at the IndiaBangladeshi border, to the east of the Himalayas. The Bhagirathi River, located in the upper Ganga basin, is one of the main head streams of the Ganges. The Bhagirathi River originates from Gaumukh 3920 ma.s.l. at the terminus of the Gangotri glacier in Uttarakhand, India (Bajracharya and Shrestha, 2011). The Tehri dam is located on this tributary, providing the most central data point on the Himalayan arc in this analysis (not a GRDC gauge).

The Karnali River (also known as Ghaghara), drains from the Himalayas originating in Nepal flowing across the border to India where it drains into the Ganges. The Karnali is the largest river in Nepal and a major tributary of the Ganges (Bajracharya and Shrestha, 2011) accounting for approximately $11 \%$ of the Ganges discharge, $5 \%$ of its area and $12 \%$ of its snowfall in the HNRCMs. Two of the river gauges in this analysis, the Benighat and the Chisapani, are located on this river. Two other sub-catchments complete those covering the Ganges basin; the Narayani and the Arun rivers. The Narayani River (also known as the Gandaki River, represented here by the Devghat river gauge) is reportedly very dependant on glaciers at low flow times of the year with over 1700 glaciers covering more than $2200 \mathrm{~km}^{2}$ (Bajracharya and Shrestha, 2011). The Arun River, part of the Koshi river basin originates in Tibet, flows south through the Himalayas to Nepal. The Arun, represented in this analysis by the Turkeghat gauge, joins the Koshi river, which flows in a south-west direction as a tributary of the Ganges.

The Brahmaputra originates from the glaciers of Mount Kailash at more than $5000 \mathrm{~m}$ a.s.l., on the northern side of the Himalayas in Tibet flowing into India, and Bangladesh before merging with the Padma in the Ganges Delta. The Brahmaputra is prone to flooding due to its surrounding orography and the amount of rainfall the catchment receives (Dhar and Nandargi, 2000). The Brahmaputra is represented in this analysis by three gauges: Yangcun, the highest upstream gauge, Pandu in the middle and Bahadurabad furthest downstream but above the merge with the Padma.

There are no known observation errors for the GRDC observations (personal communication, GRDC). Estimates of observation errors for river gauges vary in the literature with a recommendation in Falloon et al. (2011) for GCMs to be consistently within $20 \%$ of the observations, while Oki et al. (1999) suggest that errors of $5 \%$ at the $95 \%$ confidence interval might be expected. McMillan et al. (2010) proposed a method for quantifying the uncertainty in river discharge measurements by defining confidence bounds. In this analysis, these methods are hindered by the lack of observations concurrent with the model simulations. Therefore, the method for approximating the inter-annual variability in this analysis is based on the model variability and is described in Sect. 2.3.

\subsection{Methods}

There are two stages to the analysis presented, comparison of the simulations with observations (for both RCM precipitation and river flows) and analysis of future climate. The comparison against observations aims to assess if the RCM reproduces the regional hydrology in terms of precipitation and river flow compared with available observations. The objective of the analysis of future climate is to understand how these simulations compare against the present-day high and low flows, i.e. present-day natural variability. In this section we describe the methods used in each stage of the 
analysis; the comparison against observations is described in Sect. 2.3.1 and the analysis of future river flows in Sect. 2.3.2.

\subsubsection{Comparison against observations}

The total precipitation from each of the downscaled GCM simulations are compared against a downscaled ERA-Interim simulation and APHRODITE observations. This comparison is on the basin scale, focussing on the basins included in the river-flow analysis (see Sect. 2.2): the Indus and the Ganges-Brahmaputra. The TRIP model basin boundaries for each of these basins are shown in Fig. 4. The Ganges and Brahmaputra catchments are considered together in this analysis as these rivers join together in the Ganges Delta and are not clearly delineated in TRIP (see Fig. 4b). The precipitation patterns for each basin are useful for understanding the changes in the river flows within the catchments although rain gauges in the APHRODITE data set are particularly sparse at higher elevations (see Yatagai et al., 2012, Fig. 1). This leads to underestimation of the basin wide water budgets particularly for mountainous regions (Andermann et al., 2011). This is confirmed by Immerzeel et al. (2015) for the Indus basin where they find a high altitude precipitation of up to 10 times higher than current gridded data sets is needed to close the water balance for this basin. We compare the observations and simulations in terms of their annual time series and the climatology for each basin. The climatologies are calculated using the 1971-2000 period for HadCM3 and ECHAM5 and 1990-2006 for the ERAint simulation in order to capture a typical seasonal cycle for each simulation and basin.

This analysis is repeated for river flows in Sect. 3.2 for each of the 12 gauges described in Sect. 2.2. We also calculate the $1.5 \mathrm{SD}$ (standard deviation) over a 30 -year period to define the inter-annual variability. A value of plus $1.5 \mathrm{SD}$ indicates an $\sim 1$ in 10-year wet event, and a value of minus $1.5 \mathrm{SD}$ indicates a 1 in 10-year dry event. This approach is taken to indicate the possible impact of such a change under the hypothesis that current socio-economic levels of climate adaptation can cope with a 1 in 10-year event. The change driving mechanism could be anthropogenic climate or decadal variability. This assumes that inter-annual variability is independent of climate change whether that is due to decadal variability or externally forced change. In this context it is indicative of the timing and magnitude of possible changes under the A1B emissions scenario. More work and ensemble members would be required to control the role of decadal variability while the substantial computation expense in running high-resolution RCM experiments currently precludes the use of initial condition ensembles.

\subsubsection{Future analysis}

In Sect. 3.3 we use the annual time series of the whole simulation period to highlight any trends in future precipitation, evaporation (at the basin scale) and river flows (for each gauge) over the century. We also calculate the climatologies for two future 30-year periods: 2040-2070 (referred to as the 2050s) and 2068-2098 (referred to as the 2080s). The monthly climatology for the two periods is compared against the 1971-2000 range of natural variability. The purpose of the climatology analysis is twofold. The first objective is to establish if there is any change in the seasonality of the river flow. The second objective is to establish if there is any increase in the future 30-year-mean river flows that is outside the present-day variability, thereby indicating an increase in future events that are equivalent to the 1971-2000 1 in 10year wet (dry) events (see Sect. 3.3.1).

Analysis of the 30-year mean is useful for understanding the general climatology of the region, but often it is the periods of high and low river flow that are critical in terms of water resources. Mathison et al. (2013) highlighted the importance of potential changes in the seasonal maximum and minimum river flows for the agricultural sector. The analysis in Sect. 3.3.2 uses kernel density estimation (KDE; Scott, 2009; Silverman, 1986) to calculate the probability density functions (pdfs) of the river flows for each river gauge and 30 -year period. The main aim of this analysis is to establish if there is any change in the distribution of the highest and lowest river flows for the 2050s and 2080s compared with the 1971-2000 period (see Sect. 3.3.2). Given these distributions, we then attempt to quantify the changes in the highest and lowest river flows for the two future periods by focussing on the changes in the lowest and highest $10 \%$ of flows using two different approaches. In the first approach, in Sect. 3.3.3, we apply the upper and lower $10 \%$ of river flows for the 1971-2000 period as thresholds for the 2050s and 2080s. In Sect. 3.3.4, we take the principle of the threshold analysis one step further by calculating the 10th and 90th percentile thresholds for each decade, simulation and gauge. The aim of this second approach is to establish if there is any systematic change in the upper and lower parts of the distribution through the century.

\section{Results}

The results are divided into three sections. Precipitation has a key influence on river flows; therefore, in Sect. 3.1 we consider the previous evaluation of the HNRCM simulations comparing the RCM precipitation for major South Asia basins with observations and ERAint. In Sect. 3.2 we focus on river flows themselves for 12 gauges within these basins distributed across the Himalayan arc. The methods used in Sect. 3.1 and 3.2 are described in Sect. 2.3.1. In Sect. 3.3 we analyse the future projections of precipitation, evaporation and river flow to understand the water cycle of the region (see Sect. 2.3.2 for the methods used). 


\subsection{Comparison of present-day driving data with observations}

The HNRCM simulations have been evaluated in several previous publications. Lucas-Picher et al. (2011) evaluated the ability of RCMs to capture the ASM using ERA-40 data. Kumar et al. (2013) analysed the HNRCMs forced with ERAInterim data. The GCM and HNRCM simulations are also evaluated against a range of observations for the GangesBrahmaputra river basin in Mathison et al. (2013). Figure 3 shows the observed spatial distribution of total precipitation for the monsoon period (June to September; Goswami and Xavier, 2005) together with the HadCM3 and ERAint prior to and post-downscaling. The HNRCMs (Fig. 3d and e) improve the spatial distribution of precipitation and therefore compare well with the observations shown in Fig. 3c. This is highlighted by the additional detail shown in the precipitation fields through comparison of the pre-downscaled data sets for the HadCM3 GCM (Fig. 3a) with those downscaled using HadRM3 (Fig. 3e). This comparison is also possible for the downscaled ERA-Interim reanalysis data set shown in Fig. 3d, which also shows an improved precipitation representation compared with the pre-downscaled data set (Fig. 3b). The higher-resolution orography used in the $25 \mathrm{~km}$ RCMs is more able than the much coarser-resolution data sets to capture the particularly varied terrain of this region and the effects of this on the precipitation distribution. In general the HNRCM simulations capture the spatial characteristics of the ASM, successfully reproducing regions of high convective precipitation, maximum land rainfall and the rain shadow over the east coast of India (Kumar et al., 2013). Through adequately representing the spatial precipitation characteristics across the region, the areas of maximum and minimum precipitation can have a direct impact on the river flows for the appropriate basin. This is shown by the improvement in the timing and magnitude of the maximum precipitation for the RCM (HadRM3) compared with the GCM (HadCM3) shown in Fig. 6c (Indus) and Fig. 6d (Ganges-Brahmaputra). The RCMs are also able to reproduce the inter-annual variability of the region although they underestimate the magnitude of the variation (Kumar et al., 2013). The GCMs in the AR4 ensemble tend to exhibit cold and wet biases compared to observations both globally (Nohara et al., 2006) and for South Asia (Christensen et al., 2007). Although these are generally reduced in the RCM simulations there is a cold bias in the RCM that is probably carried over from the larger bias in the GCMs (Mathison et al., 2013; Kumar et al., 2013).

The remaining analysis focusses on the downscaled simulations of HadCM3, ECHAM5 and ERAint using the HadRM3 RCM. The RCM simulations shown in Fig. 6 appear to overestimate the seasonal cycle of total precipitation compared with the APHRODITE observations; this is highlighted by the annual mean of the total precipitation shown in Fig. 5. However, given the limitations of the observa-

\section{Present-day JJAS mean for total precipitation}
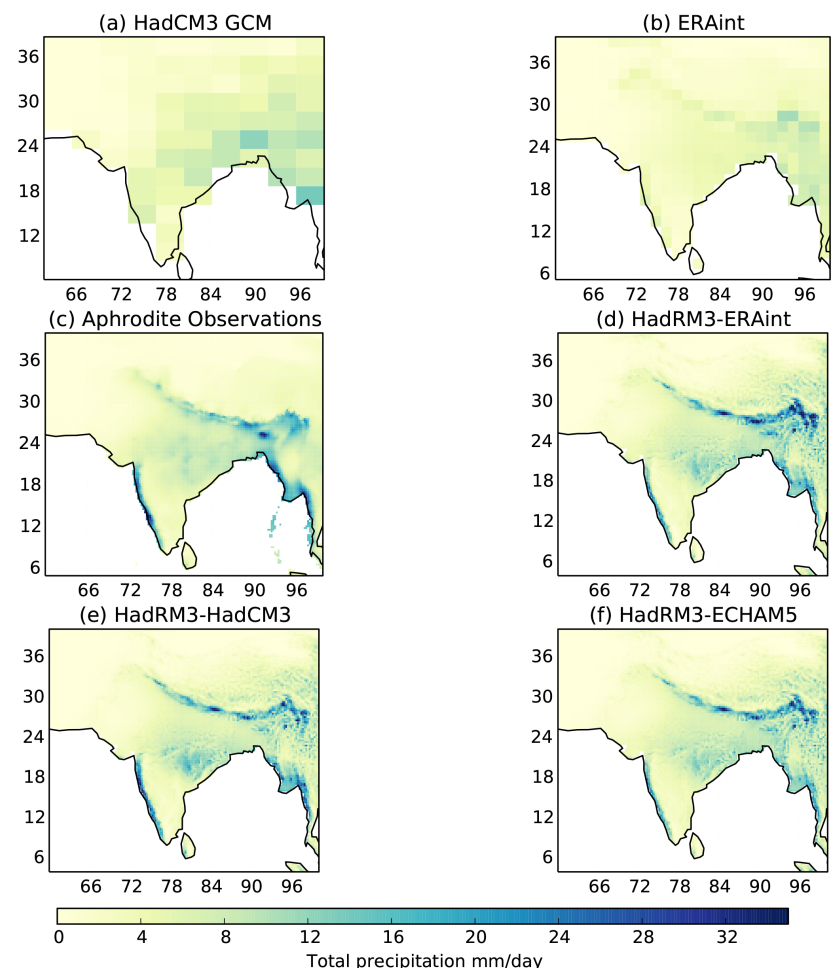

Figure 3. The spatial distribution of the seasonal mean total precipitation for the monsoon period (June, July, August, September) for the HadCM3 GCM (a), ERAint (b), APHRODITE observations (c) and the three HadRM3 simulations: HadRM3-ERAint (d), HadRM3-HadCM3 (e) and HadRM3-ECHAM5 (f).

tions at high elevations discussed in Sect. 2.3.1 we compare HadCM3 and ECHAM5 against an ERAint simulation. The annual mean (Fig. 5) and the monthly climatology (Fig. 6) show that, for these catchments, the ERAint simulation lies between the two HighNoon ensemble members for much of the year. However, during peak periods of precipitation the magnitude of total precipitation for ERAint is larger.

The seasonal cycles of total precipitation are distinctly different between the basins shown. The Indus basin (Fig. 6a), indicates two periods of precipitation: one smaller peak between January and May and another larger one between July and September. The timings of the largest peaks compare well; however, the smaller peak occur later than both ERAint and APHRODITE for ECHAM5 and HadCM3. The magnitude of the peaks in precipitation in the APHRODITE observations are consistently lower throughout the year than the simulations. The magnitude of the ERAint total precipitation is typically the largest while the ECHAM5 simulation is the lowest and closest to the APHRODITE observations. HadCM3 is between ECHAM5 and ERAint for most of the year. In contrast the Ganges-Brahmaputra catchment (Fig. 6b) has one strong peak between July and September. 


\section{Basin outlines from TRIP}
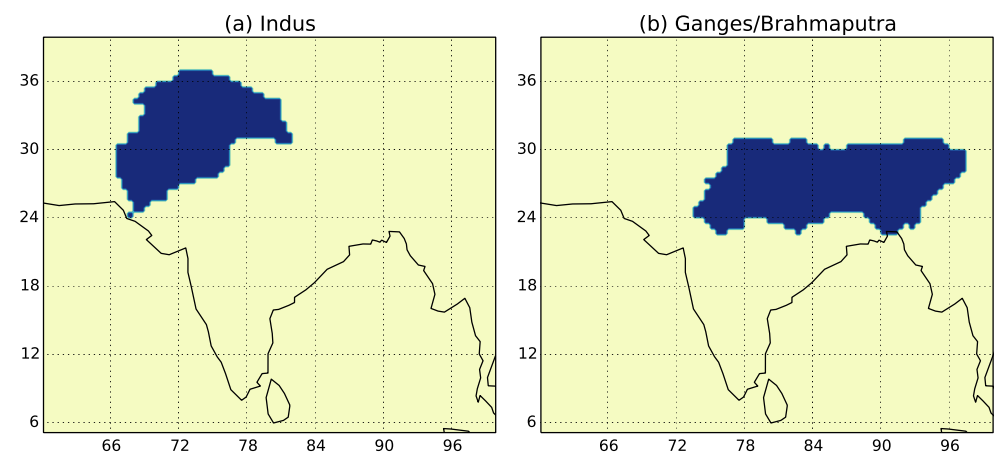

Figure 4. The outline of the basins within the TRIP model; Indus (a) and Ganges-Brahmaputra (b).

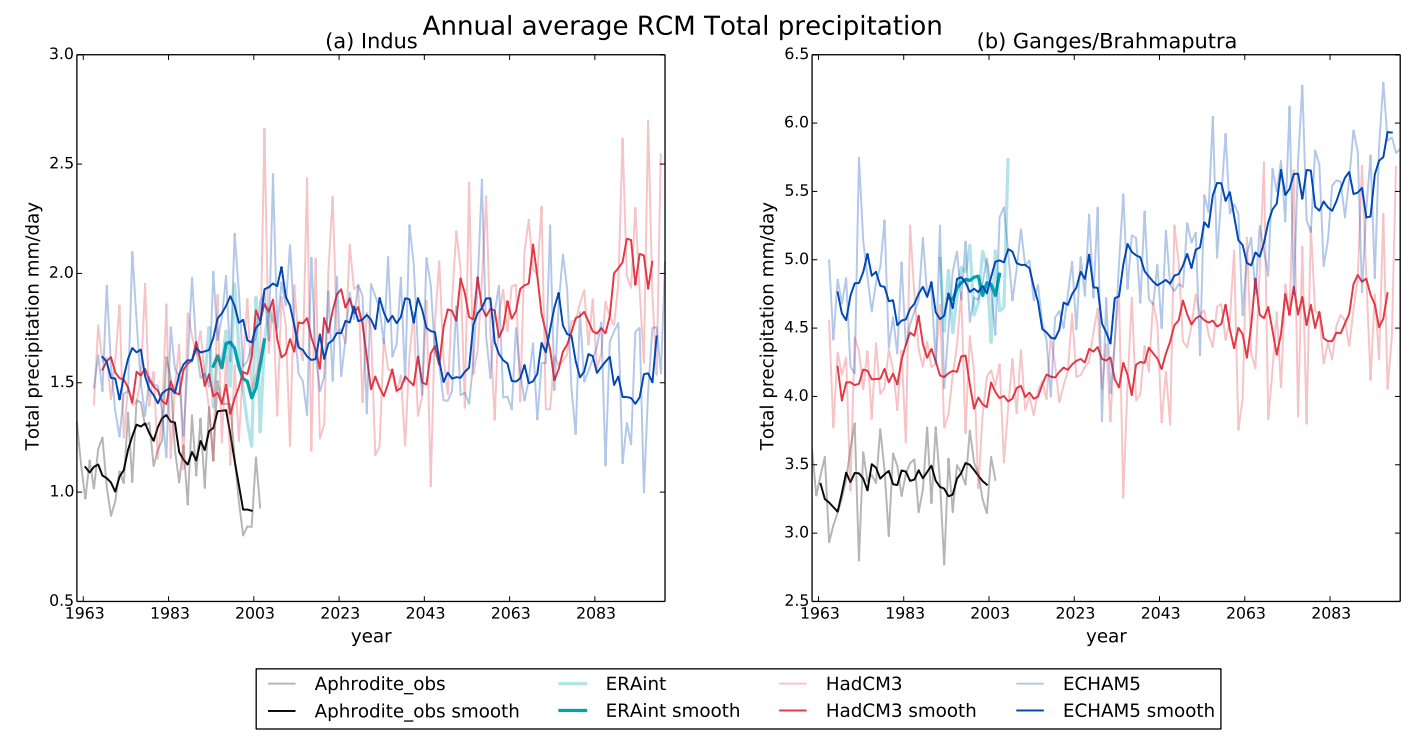

Figure 5. Annual mean total precipitation for the Indus (a) and Ganges-Brahmaputra (b) catchments for each model run (HadCM3 - red, ECHAM5 - blue, ERAint - cyan lines) plotted against APHRODITE observations (black line). Paler observations are annual averages and darker lines are a 5-year rolling smoothed average.

In general this seasonal cycle is captured reasonably well by the simulations, both in terms of magnitude and timing of the highest period of precipitation. However, there is a tendency for the simulations to overestimate rainfall between January and June compared to the observations, thus lengthening the wet season (Mathison et al., 2013). Mathison et al. (2013) also showed that in these simulations, the region of maximum precipitation along the Himalayan foothills is displaced slightly to the north of that shown in the observations. One explanation for this could be that the peak in total precipitation is due to the distribution of observations already discussed. Alternatively, it could be due to the model resolution, which may still be too coarse to adequately capture the influence of the orography on the region of maximum precipitation. The downscaled ERAint simulation also indicates a higher total precipitation for January-May that is within the range of uncertainty of the GCM driven simulations. However, for the remainder of the monsoon period, ERAint has a higher total precipitation than the GCM driven simulations. Figure $3 d$ illustrates this, showing a slightly larger and more intense area of maximum rainfall over the eastern Himalayas for the downscaled ERAint simulation than shown in the other RCM simulations (Fig. 3e and f) or APHRODITE (Fig. 3c).

\subsection{Present-day modelled river flows}

In this section we compare present-day modelled river flows with observations and a downscaled ERAint simulation, using annual average river flows (see Fig. 8) and monthly cli- 

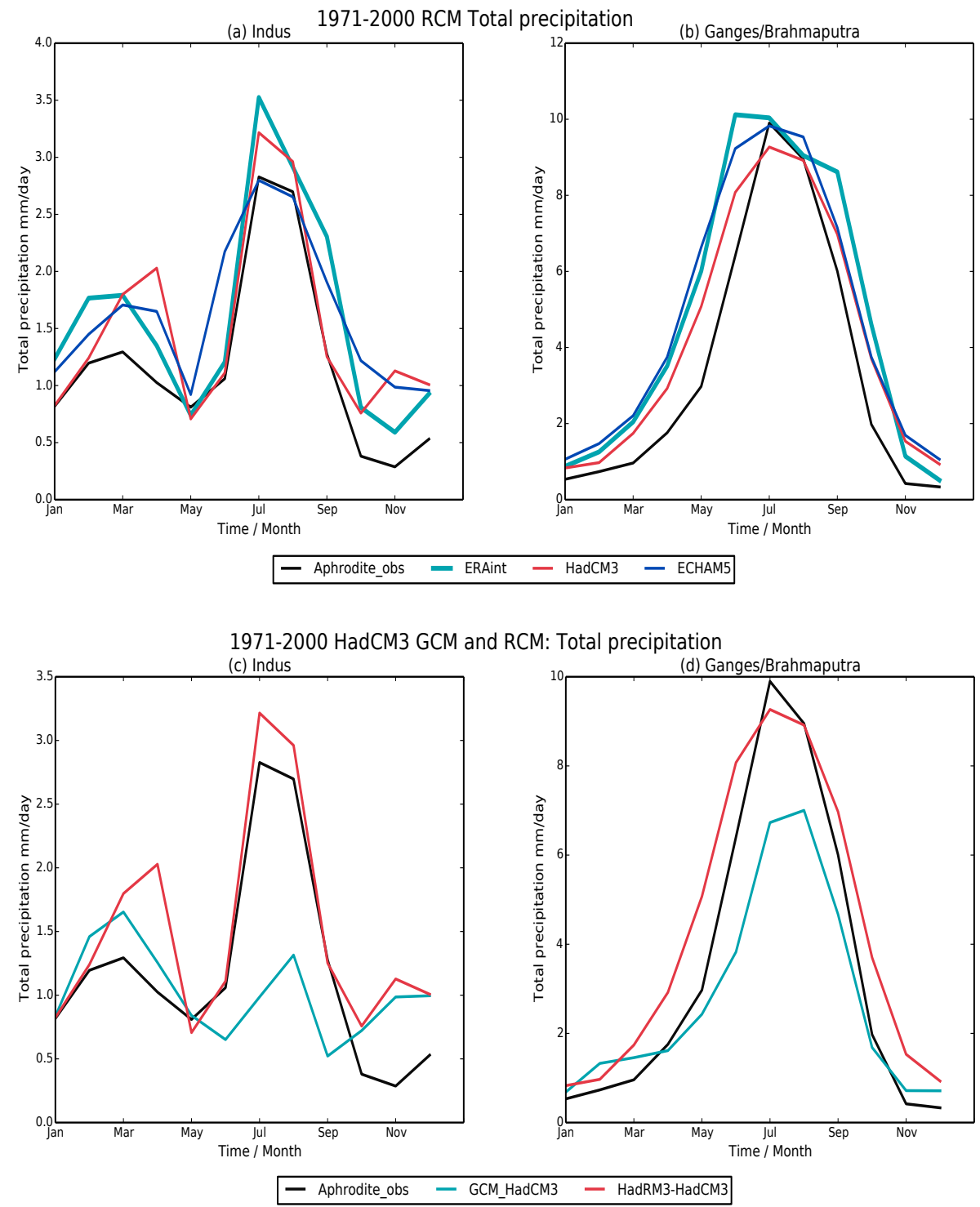

Figure 6. Seasonal cycle of total precipitation for the Indus (a, c) and Ganges-Brahmaputra (b, d) catchments. The RCM simulations are shown in (a) and (b) (HadCM3 - red, ECHAM5 - blue, ERAint - cyan lines). A comparison of the HadCM3 GCM (cyan line) and HadCM3-HadRM3 (red line) seasonal cycles are shown in (c) and (d). APHRODITE observations are also shown (black line) on all plots.

matologies (see Fig. 9). It is clear from Fig. 8 that observed river-flow data are generally limited, which makes statistical analysis of the observations difficult. River-flow data for this region are considered sensitive and is therefore not readily available particularly for the present day. For each of the gauges shown here, there are generally several complete years of data but often the time the data collected pre-dates the start of the model run. The ERAint simulation is also shown (cyan line-ERAint) to provide a benchmark in the absence of well-constrained observations (see Sect. 3.1). The comparison between the model and observations shown in Figs. 8 and 9 is therefore to establish if the model and observations are comparable in terms of the average seasonal cycle and mean river-flow rate without over-interpreting how well they replicate the observations. The Tehri dam on the Bhagirathi River is not a GRDC gauge; therefore, observations are not shown. Observations for this gauge were received via personal communication from the Tehri dam operator and therefore could not be adequately referenced.

The Kotri gauge on the Indus (Fig. 9a) and the Yangcun gauge on the Brahmaputra (Fig. 9k) are the only two gauges where the modelled river flow is higher than the observations and not within the estimated variability $(1.5 \mathrm{SD})$ of the region. The ERAint simulation is also outside the estimated variability $(1.5 \mathrm{SD})$ for the Benighat gauge on the Karnali River (Fig. 9e). The differences in these gauges are also re- 


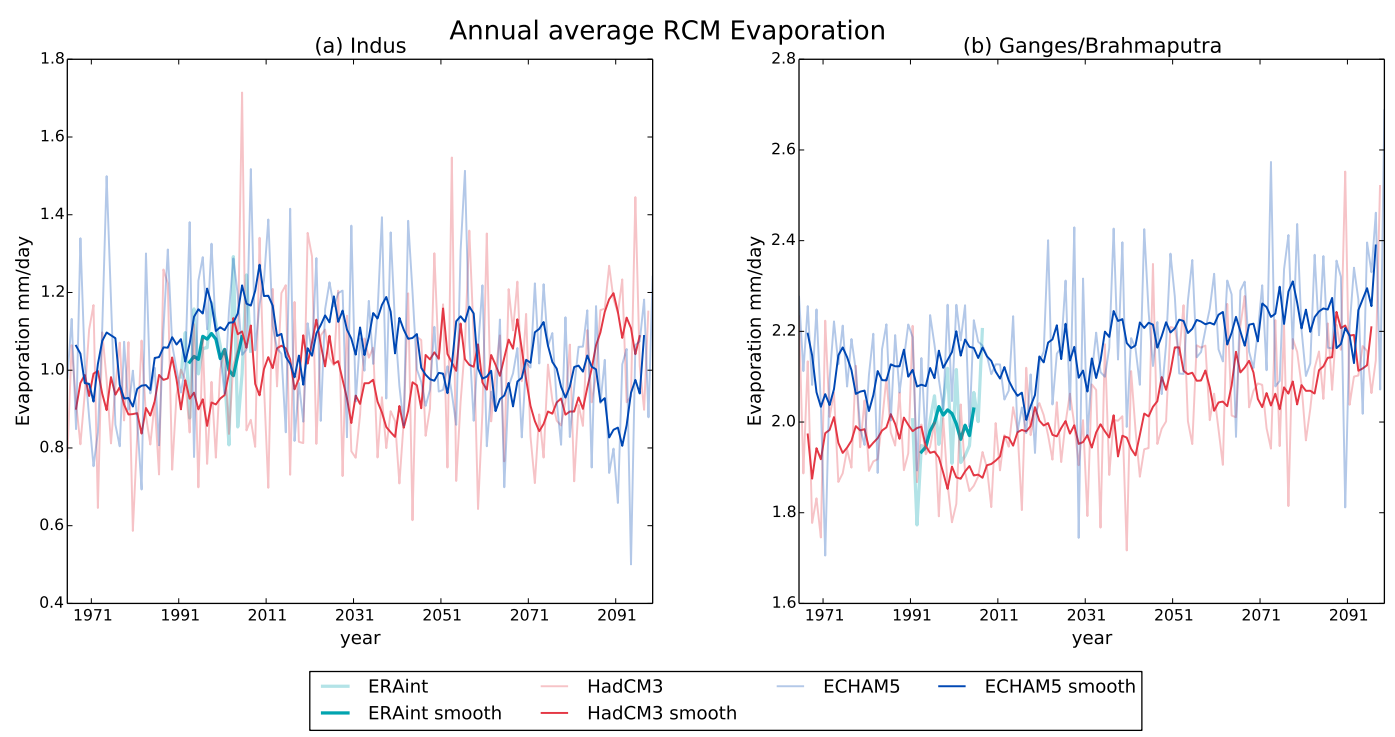

Figure 7. Annual mean evaporation for the Indus (a) and Ganges-Brahmaputra (b) catchments for each model run (HadCM3 - red, ECHAM5 - blue, ERAint - cyan lines) from 1971 to 2100. Paler lines are annual averages and darker lines are a 5-year rolling smoothed average.

flected in the annual mean river flows (Fig. 8) for these river gauges, which are higher than observed. The high bias in modelled river flow at the Kotri gauge could be due to the extraction of water, which is not included in the model. The Indus has the largest irrigation scheme in the world and a semi-arid climate (Immerzeel et al., 2015), which means the extraction rate for this basin is large (Biemans et al., 2013). This gauge is also located relatively close to the river mouth to the west of the Himalayas (see Fig. 2 and Table 1); therefore, the river flows are less likely to be affected by the ASM and more likely to be affected by meltwater from winter precipitation. The Yangcun gauge is a more upstream gauge and the differences between the model and observations for this gauge are more likely to be related to the precipitation distribution. Figure 3 shows a region of intense precipitation in the simulations (Fig. 3d-f) for the ASM period close to this gauge. The APHRODITE data (Fig. 3c) also show a region of higher rainfall although this is not as large as that shown for the simulations. This could be having a direct effect on the river flow.

The other two gauges on the Brahmaputra are located downstream of the Yangcun gauge: the Pandu (Fig. 91) and Bahadurabad (Fig. 9j). At these two gauges, the seasonal cycle of river flow has a very broad peak particularly in the modelled river flows compared to the other gauges. In the simulations the snowfall climatology for the GangesBrahmaputra basin (not shown) has a similar seasonal cycle to that of the river flow for the Bahadurabad and the Pandu gauges. It is therefore likely that the broad peak in river flow is related to the broad peak in snowfall and subsequent snowmelt. The Pandu gauge is also one of only two gauges where the modelled river flow is less than the observations for at least part of the year, the other being the Devghat gauge on the Narayani River (Fig. 9g). Both of these gauges are located in the Himalayan foothills close to the region of simulated maximum total precipitation. If the simulations put the location of this maximum below these gauges this could cause the river flows at the gauges to be lower than observed. The river flow on the main trunk of the Ganges at the Farakka Barrage (shown in Fig. 9i) is a reasonable approximation to the observations in terms of magnitude; however, the timing of the peak flow seems to be later in the models. It could be argued this also happens in some of the other gauges although it is more noticeable for the Farakka Barrage. All the gauges shown here are for glacierized river basins. Snow fields and snowmelt are represented in the simulations in this analysis and will therefore replicate some aspects of melt affecting river flow. However, glacial melt is not explicitly represented in the RCM used for these simulations. Including glacial processes specifically could act to reduce runoff because more snow is stored as ice or increase runoff where there is an increased melting (Bolch et al., 2012). Therefore, including glacial processes could be important for the timing and magnitude of the maximum and minimum river flows for these catchments.

\subsection{Future river flows}

In this section we consider the future HNRCM simulations. Figure 5 highlights the variability in the future projections of total precipitation for South Asia between basins. In these simulations the Ganges-Brahmaputra catchment shows an increasing trend in total precipitation and there is considerable variation between the simulations (Fig. 5b). The Indus basin (Fig. 5a), however, has a much flatter trajectory to 2100 and the simulations are more similar. The annual time 

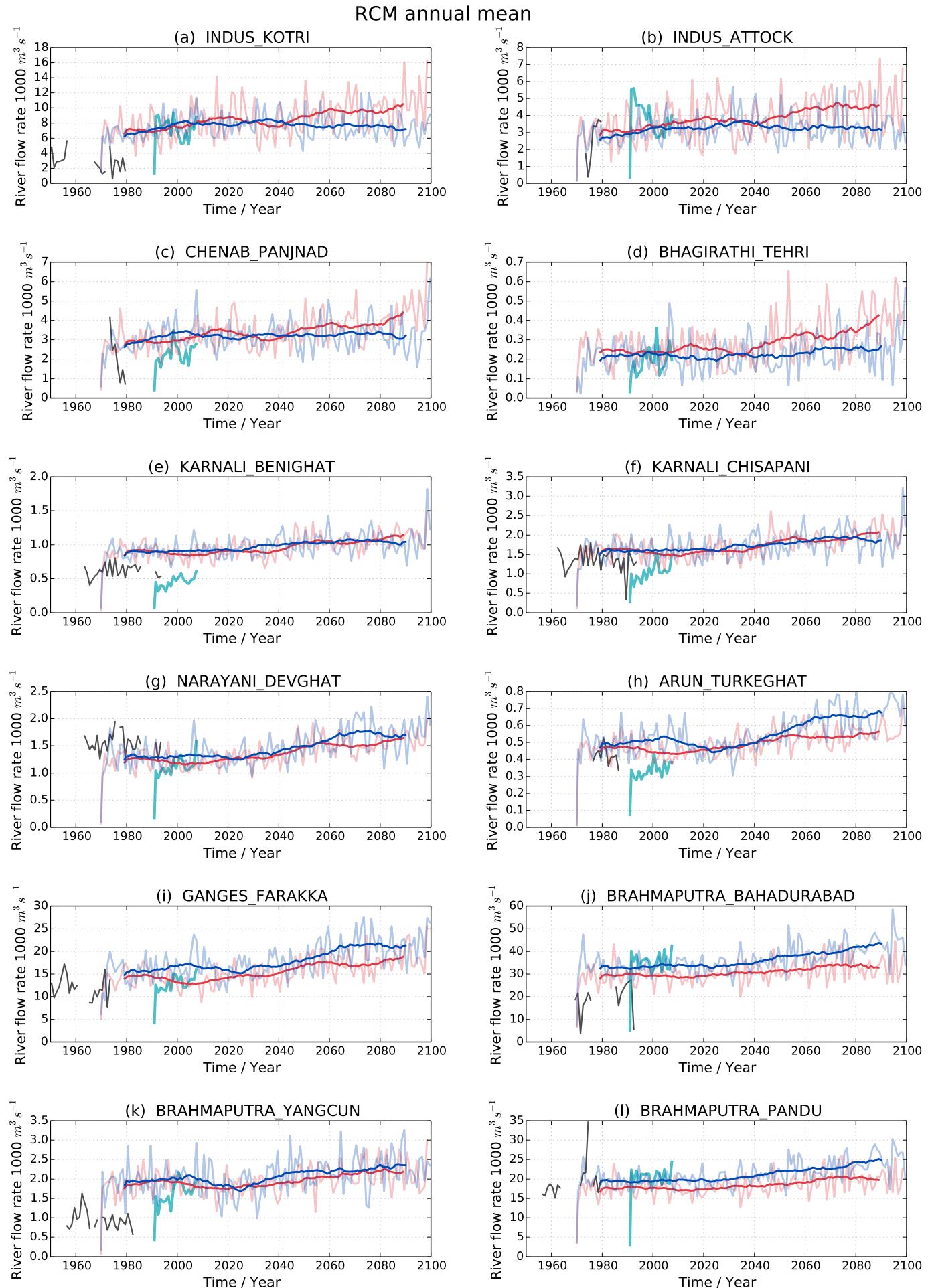

\begin{tabular}{|c|c|c|c|c|c|}
\hline - & Observed & - & HadCM3 & - & $\begin{array}{l}\text { ECHAM5 } \\
\text { FCHAM5 }\end{array}$ \\
\hline
\end{tabular}

Figure 8. Time series of river flows showing available observations (black) and RCM runs (HadCM3 - red, ECHAM5 - blue, ERAint - cyan lines) from 1971 to 2100 . Paler lines are annual averages and darker lines are a 20-year rolling smoothed average. 

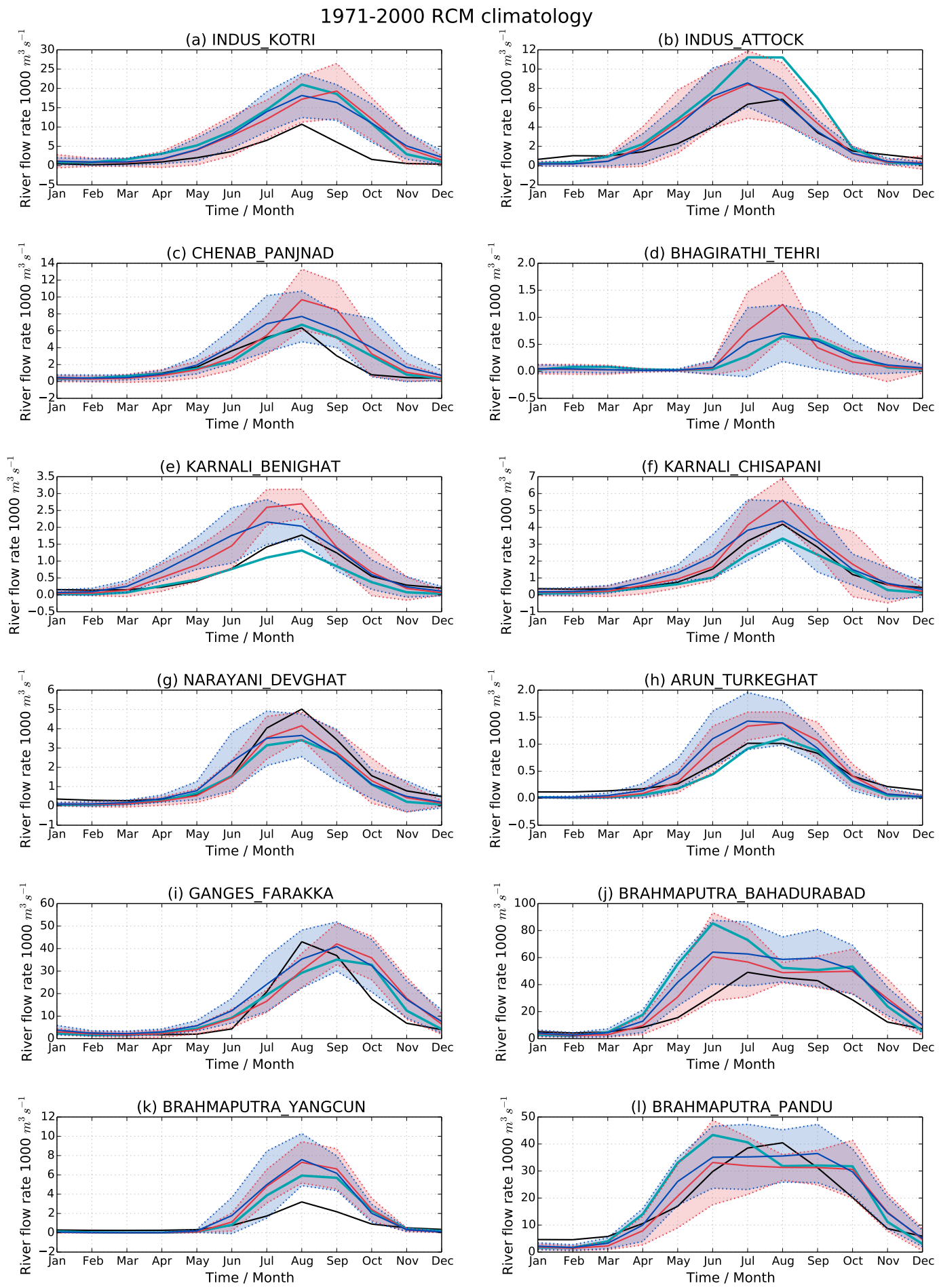

\begin{tabular}{|c|c|c|c|c|}
\hline - & Observed & - & HadCM3 & 1971-2000 1.5 stdev HadCM3 \\
\hline - & ERAint & - & ECHAM5 & $1971-20001.5$ stdev ECHAM5 \\
\hline
\end{tabular}

Figure 9. Seasonal cycle of river flow at individual river gauges; observed (black solid line) and for each of the RCMs (HadCM3 - red, ECHAM5 - blue, ERAint - cyan lines) from 1971 to 2000; with shaded regions showing 1.5 SD from the mean for the two simulations for the same period. 
series of evaporation (Fig. 7) over these catchments shows a similar picture, with an increasing trend for the GangesBrahmaputra basin (Fig. 7b) but no real trend for the Indus (Fig. 7a). The annual mean runoff efficiency (not shown), defined here as the ratio of annual runoff (streamflow per unit area) to annual precipitation, shows no real trend for either basin. The trends in river flow (see Fig. 8) vary between gauges, although none indicate decreasing river flows. There is an upward trend in river flows at some of the gauges, in particular, the Narayani-Devghat (Fig. 8g), Arun-Turkeghat (Fig. 8h) and Ganges-Farakka (Fig. 8i). These gauges suggest an upward trend toward the 2100s that actually represents a doubling of the river-flow rate. The increase in river flow for the Narayani-Devghat gauge (Fig. 8g) are consistent with analysis by Shrestha and Aryal (2011) using a hydrological model for the Narayani basin. Ganges-Farakka is the most downstream gauge in the Ganges-Brahmaputra basin in this river-flow analysis, therefore providing an approximation for the whole Ganges basin. These simulations show an increase in precipitation for the Ganges-Brahmaputra basin of approximately $20 \%$ (see Fig. 5) and an increase of approximately $10 \%$ in evaporation (see Fig. 7), over the course of the century. This suggests the changes in runoff over the Ganges catchment are predominantly driven by precipitation on the annual scale. However, regional analysis by Jhajharia et al. (2012) covering the humid north-eastern part of India and a global analysis by McVicar et al. (2012) suggested there has been a decline in the evaporation caused by lighter surface winds and reduced radiation. A future reduction in evaporation could also contribute to future increases in runoff. Analysis using a conceptual hydrological model by Singh and Bengtsson (2005) suggested that the type of precipitation being received at different elevations and the changes in melt and evaporation from snowpacks in a warmer climate could also be important for changes in runoff.

\subsubsection{Climatology analysis}

In this section we use climatologies to compare future river flows with the present-day inter-annual variability (defined in Sect. 2.3.1). South Asia is a very variable region, yet these models suggest the future mean river flow could lie outside the present-day variability for peak flows for some of the gauges in this study. This could have important implications for water resources for the region. The gauges that show an increase in maximum river flows (see Fig. 10) are mainly those in the middle of the Himalayan arc (see Fig. 2). The seasonal cycle for the western most gauges (located in the Indus basin) and the eastern most gauges (located in the Brahmaputra basin) are typically still within the range of present-day variability. This could be due to the changes in the influence on river flow from west to east becoming more influenced by the ASM and less by western disturbances, with basins in the centre of the Himalayas and to the north influenced by both phenomena. Figure 10 also suggests that the maximum river flows still occur mainly during the ASM for many of the gauges shown.

\subsubsection{High and low flow analysis}

The analysis of the high and low flows is of particular importance to water resources and future availability, therefore in this section we calculate the distributions of the river flows for each of the gauges (see Sect. 2.3.1). These are shown in the form of pdfs in Fig. 11 for the 1971-2000, 2050s and the 2080s. Figure 11 illustrates how the lowest flows dominate the distributions for each of the three periods. In most of the gauges 1971-2000 period has the highest frequency of the lowest flows, the curves then tend to flatten in the middle of the distribution before tailing off toward zero for the highest flows. The two future periods also follow a similar trajectory, although in general there is a reduction in the frequency of the lowest flows and an increase in the magnitude of the highest flows for all of the gauges and both simulations towards 2100 .

The Yangcun gauge on the Brahmaputra (Fig. 11k) shows the least change of all the gauges between the 1971-2000 period, future periods and simulations. The distributions for the gauges downstream of Yangcun, the Pandu (Fig. 111) and the Bahadurabad (Fig. 11j), are notable for their differences from all the other gauges. All the other gauges shown have a single peak toward the lower end of the river-flow distribution. The Pandu and Bahadurabad gauges have two distinct peaks in frequency with a second peak occurring toward the middle of the distribution, where the distribution for most other gauges flattens out. This is consistent with the broader peak in the 30-year mean seasonal cycle shown for these gauges in Fig. 10 and is probably similarly explained by snowmelt (see Sect. 3.2). In some of the other gauges there is a small increase in the middle of the river flow distribution but this tends to be smaller and restricted to the two future periods, e.g. the two Karnali River gauges (Fig. 11e and f).

\subsubsection{Threshold analysis}

The pdfs shown in Fig. 11 and described in Sect. 3.3.2 suggest future changes in the lower and upper ends of the riverflow distribution. In this section we consider these parts of the distribution in order to confirm this pattern. We compare the two future periods (2050s and 2080s) against the 1971-2000 period explicitly using thresholds defined by the 10th and 90th percentiles for this present-day period for each river gauge. Graphical examples from the results of this analysis are shown for all three periods - historical (a), 2050s (b), 2080s (c) - for the Farakka Barrage on the Ganges in Figs. 12 and 13. In Fig. 12 the number of months where river flow is below the present-day 10th percentile reduces in each of the future decades. However, for flows greater than the presentday 90th percentile there is an increase in each of the future decades (Fig. 13). Table 2 illustrates that the patterns shown 

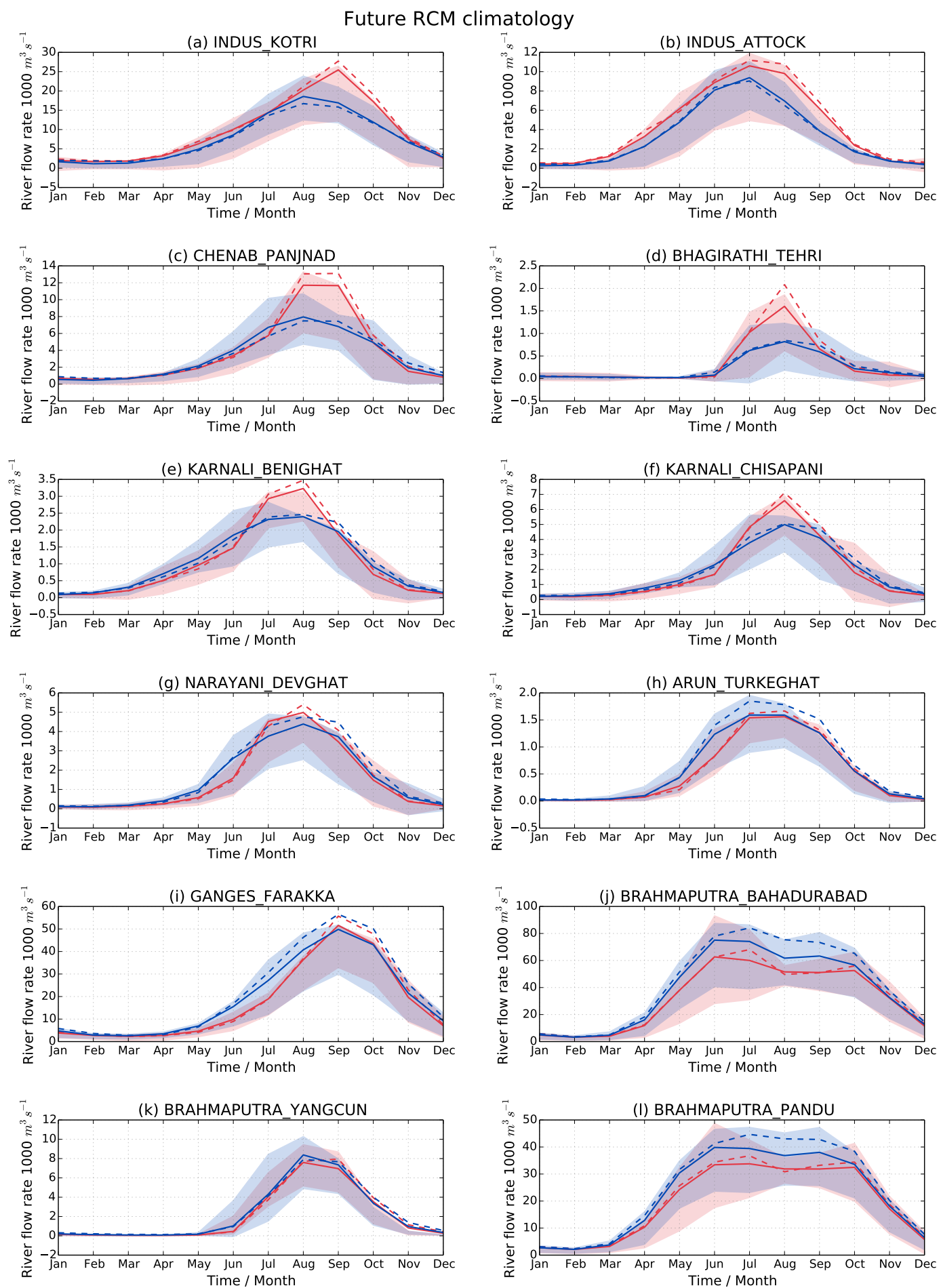

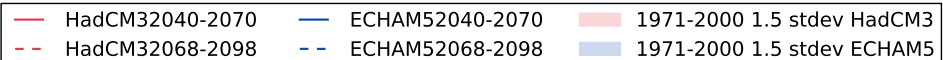

Figure 10. Seasonal cycle of river flow in each of the RCMs (HadCM3 - red, ECHAM5 - blue) for the two future periods: 2050s (solid lines) and 2080s (dashed lines), with shaded regions showing 1.5 SD from the mean for 1971-2000 for each river gauge. 

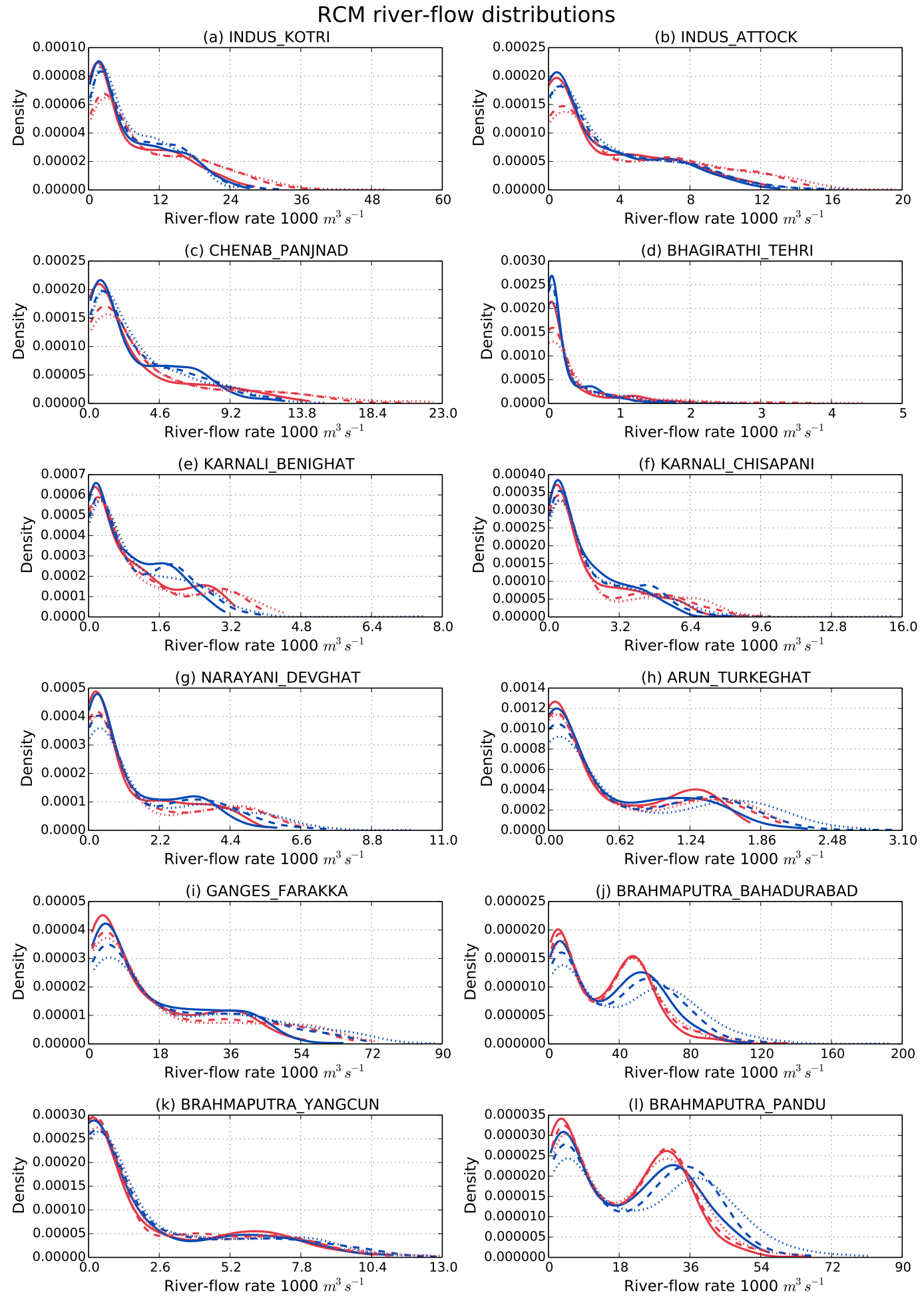

\begin{tabular}{|c|c|c|c|}
\hline 1971-2000:HadCM3 & 2040-2070:HadCM3 & …. & 2068-2098:HadCM3 \\
\hline 1971-2000:ECHAM5 & 2040-2070:ECHAM5 & $\cdots \cdots$ & 2068-2098:ECHAM5 \\
\hline
\end{tabular}

Figure 11. The distribution of the river flow in the HadCM3 and ECHAM5 (HadCM3 - red, ECHAM5 - blue) runs for three periods: historical (1971-2000 - solid lines) and two future periods (2050s - dashed lines and 2080s - dotted lines) plotted as a pdf for each river gauge. 
GANGES_FARAKKA

(a) Years where river flow $<10$ th $\%$ ile for $1971-2000$

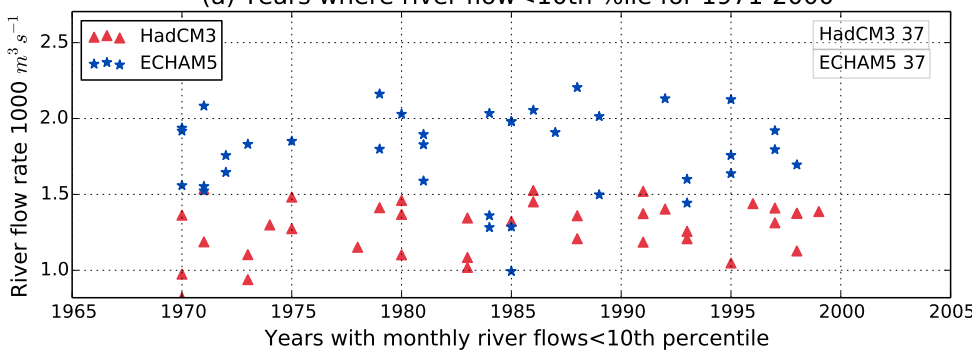

(b) Years where river flow $<10$ th $\%$ ile for $1971-2000$

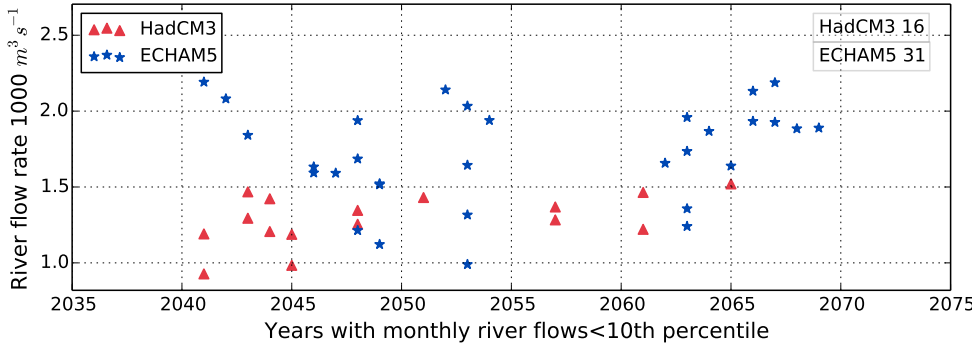

(c) Years where river flow $<10$ th \%ile for $1971-2000$

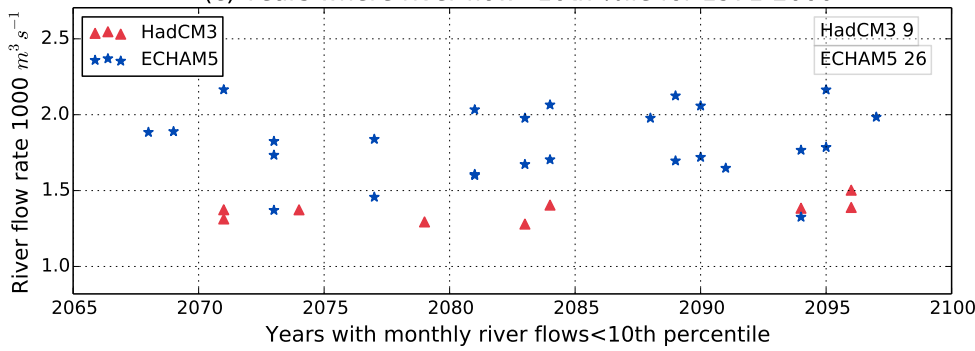

Figure 12. Comparison of the lowest $10 \%$ of monthly river flows at the Farakka Barrage on the Ganges River against the 10th percentile for the 1971-2000 period for 1971-2000 (top panel), 2050s (middle panel) and 2080s (bottom panel) for HadCM3 (red triangles) and ECHAM5 (blue stars). Each star or triangle represents a month within the 30-year period where the value is less than the 10th percentile of the 1971-2000 period with the total number for each of the simulations given in the top right corner of each plot.

in Figs. 12 and 13 are generally true for almost every other gauge in the analysis. The Tehri dam (Bhagirathi) is the only exception of the gauges shown in Table 2, showing an increase of $12 \%$ in the number of incidences where the river flow is less than the 1971-2000 10th percentile for the 2080s. This is mainly due to the ECHAM5 model which has a high number of incidences. The Yangcun gauge (Brahmaputra) is the only gauge where there is no change in the number of incidences where the river flow is less than the 10th percentile for 1971-2000 in either of the future periods. This is probably because the lowest river flows are already very low at this gauge.

At every gauge there is an increase in the number of incidences where river flows are greater than the 90th percentile for 1971-2000 for the two future periods. Several of the gauges have increases in the number of events above the 90th percentile for the 1971-2000 period of more than $100 \%$. This confirms the conclusions drawn visually from the analysis in Fig. 11 that the general distributions move toward the higher flows for these gauges and simulations.

\subsubsection{Decadal percentile analysis}

The annual time series shown in Fig. 8 is very variable and systematic changes throughout the century could be masked by this variability. The 10th and 90th percentiles for each decade and each simulation are calculated on the basis that there are changes in the upper and lower parts of the future river-flow distributions. At the lower end of the distribution, there is little change in the 10th percentile (not shown) for most of the gauges, probably because of very low flows at the lowest times of the year. Only the Pandu and Bahadurabad gauges on the Brahmaputra and the Farakka gauge on the Ganges show a non-zero value for the lowest $10 \%$ of river flows through to the $2100 \mathrm{~s}$. These three gauges indicate a slight increase for the 10th percentile for each decade through to 2100 . 
GANGES_FARAKKA

(a) Years where river flow $>90$ th $\%$ ile for $1971-2000$

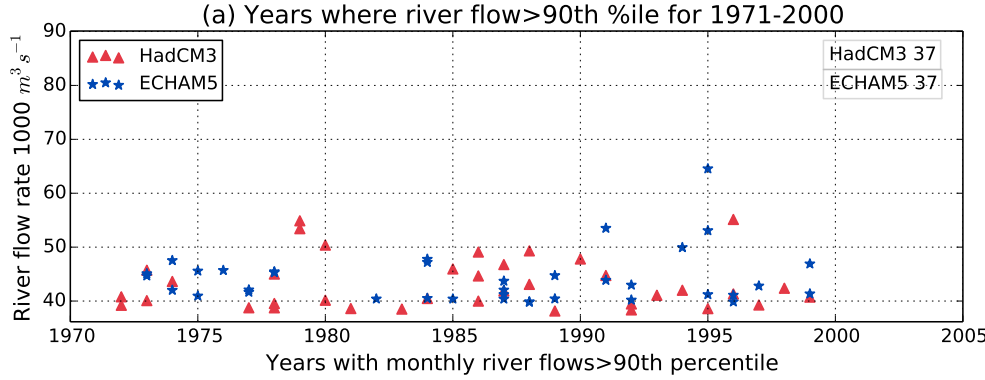

(b) Years where river flow $>90$ th \%ile for $1971-2000$

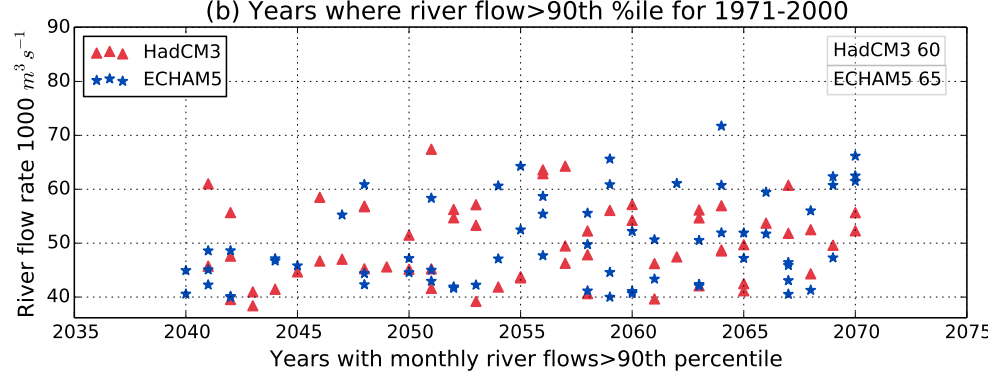

(c) Years where river flow $>90$ th \%ile for $1971-2000$

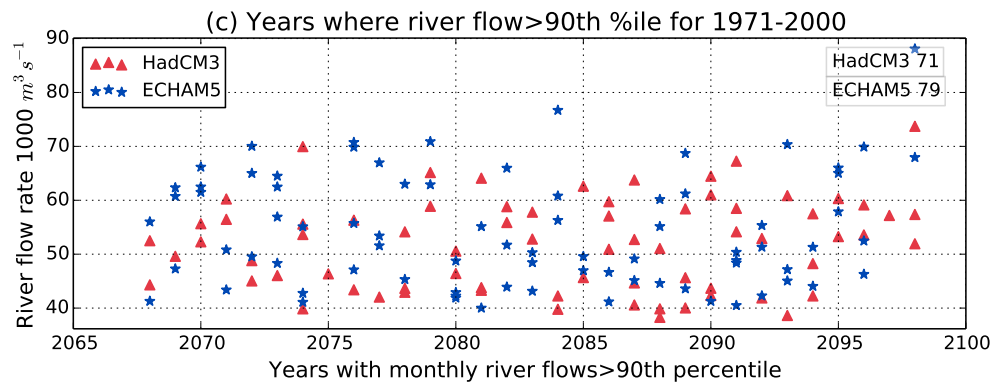

Figure 13. Comparison of the highest $10 \%$ of monthly river flows at the Farakka Barrage on the Ganges River against the 90th percentile for the 1971-2000 period for 1971-2000 (top panel), 2050s (middle panel) and 2080s (bottom panel) for HadCM3 (red triangles) and ECHAM5 (blue stars). Each star or triangle represents a month within the 30-year period where the value is greater than the 90th percentile of the 1971-2000 period with the total number for each of the simulations given in the top right corner of each plot.

The 90th percentile values (Fig. 14) are generally much more variable throughout the century than those for the 10th percentile to the 2100s. We consider the gauges according to their location across the Himalayan arc from west to east (see Fig. 2). The HadCM3 simulation projects an increase in river flows for the most westerly gauges in this analysis; Attock and Kotri gauges located on the Indus (see Fig. 14a and b) and the Chenab-Panjnad gauge (see Fig. 14c). ECHAM5, on the other hand, shows a much flatter trajectory for these gauges. This may be explained by the HadCM3 simulation depicting an increase in the occurrence of western disturbances and an increase in total snowfall which is not simulated by ECHAM5 (Ridley et al., 2013).

The gauges located toward the middle of the Himalayan arc generally show increases across the decades to 2100 in both models; these are the Bhagirathi-Tehri (Fig. 14d), both Karnali River gauges (Benighat - Fig. 14e and Chisapani Fig. 14f), Narayani-Devghat and Arun-Turkeghat (Fig. 14g and $h)$. There is very close agreement between the two simulations for the Narayani-Devghat, Arun-Turkeghat (Fig. 14g and $\mathrm{h}$ ) and Bhagirathi-Tehri (Fig. 14d) gauges, with the former two showing less variability between decades than the others in the analysis. The Karnali-Benighat gauge (Fig. 14e) also has less variability between the decades; however, there is a systematic difference between the two simulations that remains fairly constant across the decades. From the subset of gauges in this analysis that are the most central on the Himalayan arc, the Karnali-Chisapani gauge (Fig. 14f) has the largest variability between simulations and decades. However, this gauge still shows an increase overall in both simulations with a steeper increase for HadCM3 than ECHAM5. The closer agreement between simulations at these more central gauges may be due to the reducing influence of the western disturbances in the HadCM3 simulation from west to east across the Himalayas, therefore resulting in smaller differences between the two simulations. 
Table 2. Table showing the average percentage change for the two models in the number of times the modelled river flow is less than the 10th percentile and greater than the 90th percentile of the 19702000 period for the 2050 s and 2080s future periods.

\begin{tabular}{|c|c|c|c|c|c|}
\hline \multirow[t]{2}{*}{ River } & \multirow[t]{2}{*}{ Gauge } & \multicolumn{2}{|c|}{$\begin{array}{c}<10 \text { th percentile } \\
\% \text { change }\end{array}$} & \multicolumn{2}{|c|}{$\begin{array}{c}>90 \text { th percentile } \\
\% \text { change }\end{array}$} \\
\hline & & $2050 \mathrm{~s}$ & $2080 \mathrm{~s}$ & $2050 \mathrm{~s}$ & $2080 \mathrm{~s}$ \\
\hline Indus & Kotri & -55.4 & -89.2 & 60.8 & 55.4 \\
\hline Indus & Attock & -70.3 & -95.9 & 70.3 & 81.1 \\
\hline Karnali River & Benighat & -39.2 & -73.0 & 63.5 & 81.1 \\
\hline Karnali River & Chisapani & -27.0 & -56.8 & 60.8 & 79.7 \\
\hline Narayani & Devghat & -21.6 & -54.1 & 75.7 & 110.8 \\
\hline Arun & Turkeghat & -63.5 & -90.5 & 66.2 & 116.2 \\
\hline Brahmaputra & Yangcun & 0 & 0 & 20.3 & 36.5 \\
\hline Brahmaputra & Pandu & -59.5 & -79.7 & 47.3 & 113.5 \\
\hline Brahmaputra & Bahadurabad & -48.6 & -64.9 & 67.6 & 114.9 \\
\hline Ganges & Farakka & -36.5 & -52.7 & 68.9 & 102.7 \\
\hline Bhagirathi & Tehri dam & -4.1 & $12.2^{*}$ & 13.5 & 41.9 \\
\hline Chenab & Panjnad & -58.1 & -83.8 & 43.2 & 50.0 \\
\hline
\end{tabular}

* This value is the only positive value in the table.

The Farakka-Ganges gauge (Fig. 14i) and two of the Brahmaputra gauges - Bahadurabad (Fig. 14j) and Pandu (Fig. 14l) - represent three of the most easterly river gauges in the analysis. These gauges show an increase in both simulations through to the $2100 \mathrm{~s}$, in this case more pronounced in ECHAM5 than HadCM3 for these two Brahmaputra gauges. There is much closer agreement between the two simulations at the Farakka-Ganges gauge (Fig. 14i), which is located slightly further west than the two Brahmaputra gauges. The other Brahmaputra gauge, the Yangcun (Fig. 14k) is very variable through the century, there is a period with consecutive decades of increasing river flows in the middle of the century but over the whole century neither model shows a consistent change.

This analysis shows that neither simulation is consistently showing a systematic increase in the 90th percentile of river flows across all the gauges. Instead it highlights the changing conditions and the different behaviour of the two simulations across the Himalayan arc.

\section{Implications of changes in future river flows}

In this section we consider the implications of the projected future changes in river flows for South Asia on water resources. We highlight the broader challenges facing the region and where the current RCMs need development to represent key processes for this region. The key points from this discussion are summarised in Table 3. In the present day, water resources in South Asia are complicated, precariously balanced between excess and shortage. Parts of South Asia receive some of the largest volumes of precipitation in the world and are therefore at frequent risk of flooding and yet others regularly endure water stress. The complexity is in- creased by the competition between states and countries for resources from rivers that flow large distances crossing state and country borders, each with their own demands on resource. There is a considerable gap between the amount of water resources flowing through South Asia and the actual usable amount (Aggarwal et al., 2012), for example the total flow for the Brahmaputra basin is approximately $629 \mathrm{~km}^{3}$ of which only $24 \mathrm{~km}^{3}$ is usable (Kumar et al., 2005). There is therefore huge potential for improvements in the efficiency of systems for irrigation and domestic water supply that could ease pressures on water resources, currently and predicted, as demand increases.

In the last 50 years there have already been efficiency improvements, such as development of irrigation systems and use of high-yielding water efficient crop varieties. These improvements have fuelled the rapid development in agriculture across South Asia making the region more self-sustained and alleviating poverty (Kumar et al., 2005). However, these advances have also had a large impact on the regions river ecosystems resulting in habitat loss, reduced biodiversity (Sarkar et al., 2012) and water pollution (Vörösmarty et al., 2010). Historically arbitrary thresholds based on a percentage of the annual mean flow have been used to estimate minimum flows, but these simplistic estimates do not take account of the flow variability that is crucial for sustaining river ecosystems (Arthington et al., 2006; Smakhtin et al., 2006), referred to as environmental flows. Environmental flows are defined by Smakhtin and Anputhas (2006) as the ecologically acceptable flow regime designed to maintain a river in an agreed or predetermined state. The variability in river flows through the year have important ecological significance; for example low flows are important for algae control and therefore maintaining water quality. High flows are important for wetland flooding and preserving the river channel. When considering the implications of future changes in climate on river flows and therefore surface water resources, estimates of flow variability and minimum flows are an important consideration. However these are not easily quantified in general terms with many methods requiring calibration for applications to different regions and basins. In our simulations there is an intensification of the seasonal cycle and therefore an increase in the flow variability and a reduction in the occurrence of the lowest flows. These changes could have implications for the biodiversity of these catchments.

In India the domestic requirement for water is the highest priority but is only $5 \%$ of the total demand. Irrigation is the second highest priority accounting for a much greater proportion, approximately $80 \%$ of India's total demand for water. A significant proportion of domestic and irrigation resource comes from both ground and surface water. Biemans et al. (2013) studied future water resources for food production using the LPJmL (Lund-Potsdam-Jena managed Land) model and the HNRCMS. LPJmL also simulates groundwater extractions (Biemans et al., 2013) these are thought to be important for the Indus and parts of the Ganges but not the 
90th Percentile per decade
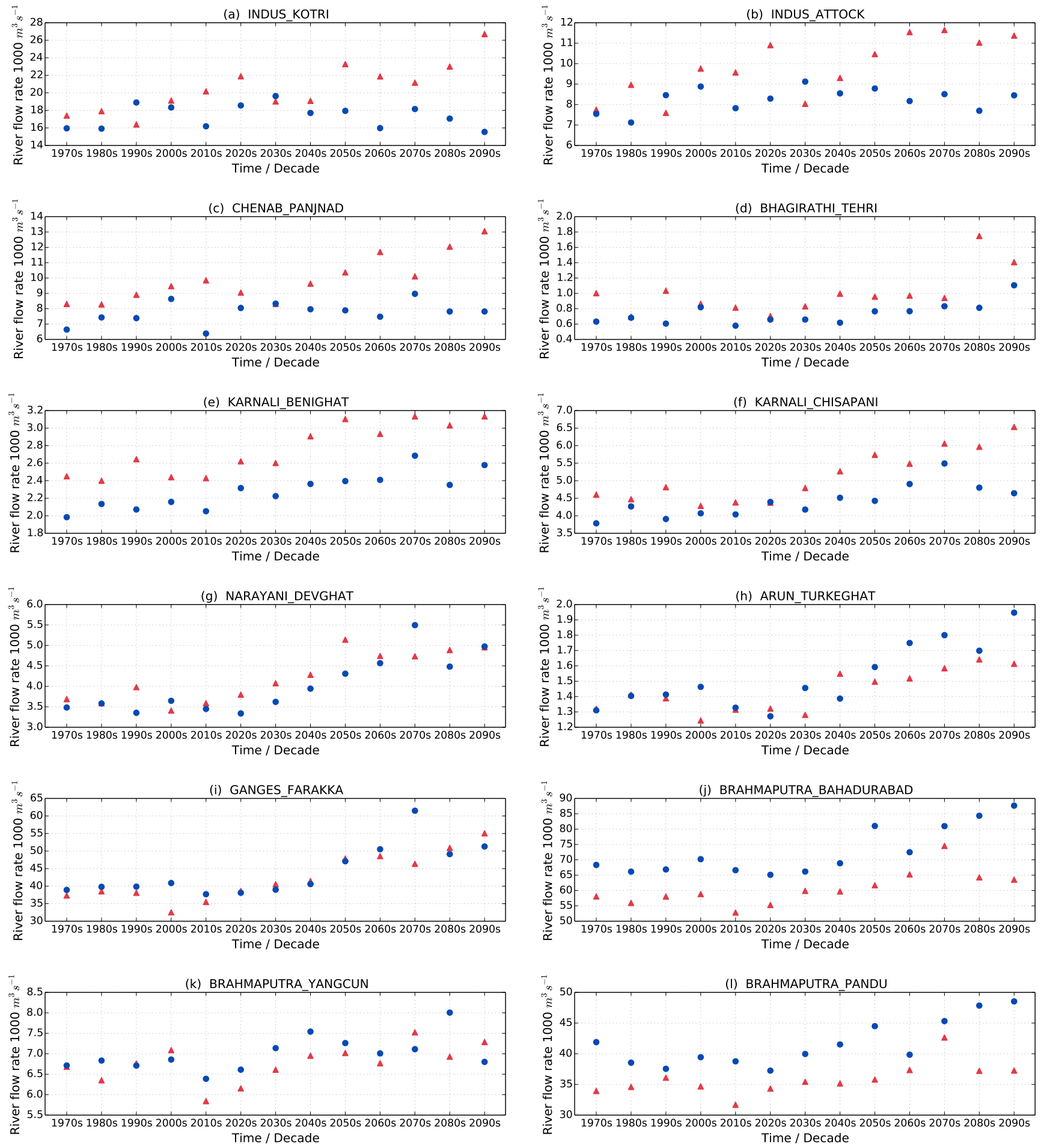

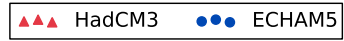

Figure 14. The 90th percentile of river flow for each decade for HadCM3 (red triangles) and ECHAM5 (blue circles) for each river gauge. 
Table 3. Table of implications of changes in water resources.

\begin{tabular}{|c|c|c|c|}
\hline Types of change & Implications for water resource & Adaptation options & Other issues \\
\hline $\begin{array}{l}\text { Large annual } \\
\text { variability }\end{array}$ & $\begin{array}{l}\text { Abundance some years and } \\
\text { scarcity in others make } \\
\text { it difficult to plan budgets } \\
\text { for different users. }\end{array}$ & $\begin{array}{l}\text { Building storage capacity } \\
\text { e.g. rainwater harvesting. } \\
\text { Improvement of irrigations systems. } \\
\text { Development of water efficient, } \\
\text { high-yielding crop varieties. }\end{array}$ & $\begin{array}{l}\text { Type of water storage is } \\
\text { important e.g. reservoirs/dams } \\
\text { have both political } \\
\text { and ecological implications. } \\
\text { Developing new crops takes time. }\end{array}$ \\
\hline $\begin{array}{l}\text { Changes in } \\
\text { peak flow - timing } \\
\text { and magnitude }\end{array}$ & $\begin{array}{l}\text { Increases in peak flows could be } \\
\text { positive for irrigation and } \\
\text { domestic supply but could increase } \\
\text { the risk of flooding. } \\
\text { Peak flows occurring later and/or } \\
\text { decreases in peak flows could reduce } \\
\text { availability of water for irrigation } \\
\text { at crucial crop development stages } \\
\text { negatively impacting yields. }\end{array}$ & $\begin{array}{l}\text { Improving river channel capacity. } \\
\text { Diverting excess water to a different valley. } \\
\text { Storing the excess water for low flow periods } \\
\text { e.g. through rainwater harvesting. } \\
\text { Improving drainage and water recycling. } \\
\text { Adopting varieties of crops that grow } \\
\text { when water for irrigation is more } \\
\text { readily available }\end{array}$ & $\begin{array}{l}\text { Flood protection levels } \\
\text { do not match demographic } \\
\text { trends so vulnerability } \\
\text { to flooding remains high } \\
\text { in this region } \\
\text { (Gupta et al., 2003). } \\
\text { Market development for } \\
\text { new crops takes time }\end{array}$ \\
\hline $\begin{array}{l}\text { Changes in low } \\
\text { flows - timing } \\
\text { and magnitude }\end{array}$ & $\begin{array}{l}\text { Increases in the magnitude of the low } \\
\text { flows could be positive for irrigation } \\
\text { and domestic supply. } \\
\text { Decreases could mean less resources } \\
\text { available for irrigation } \\
\text { leading to reduced yields }\end{array}$ & $\begin{array}{l}\text { Adaptations to avoid flooding during } \\
\text { peak flow periods could provide resources } \\
\text { during low flow periods. } \\
\text { Development of water efficient, } \\
\text { high-yielding } \\
\text { crop varieties }\end{array}$ & \\
\hline
\end{tabular}

Brahmaputra. The LPJmL simulated extraction varies considerably between basins; the largest occurring in the Indus $\left(343 \mathrm{~km}^{3} \mathrm{yr}^{-1}\right)$ followed by the Ganges $\left(281 \mathrm{~km}^{3} \mathrm{yr}^{-1}\right)$ and Brahmaputra $\left(45 \mathrm{~km}^{3} \mathrm{yr}^{-1}\right)$. The Brahmaputra has the smallest percentage of irrigated crop production (approximately $40 \%$ ) followed by the Ganges (less than $75 \%$ ) and the Indus where more than $90 \%$ of crop production is on irrigated land. The Indus has the largest proportion of water sourced from rivers and lakes of the three basins and the largest proportion of the river flow is glacial melt (Immerzeel et al., 2010).

Wiltshire et al. (2013a) use a perturbed physics ensemble of HadCM3 GCM simulations (Murphy et al., 2004) and find an increase in water resources for South Asia at the annual timescale due to climate change. The analysis shown here shows a similar result with increases in river flow, particularly the magnitudes of the higher river flows at these gauges, in some cases above the range of variability used for this analysis (1.5 SD). However, the analysis shown here on the monthly timescale, also highlights that these increases in resources tend to occur during the ASM, when river flow is at its maximum. This could mean that the benefits of an increase in water resources may not be realized due to the timing of this increase within the year. Although these projected changes in river flow are not critical for water resources they could still be beneficial where there is the capacity to store the additional flow for use during periods of low flow. Additional water storage capacity for example through rainwater harvesting, could greatly increase the useable water resources for the Ganges-Brahmaputra catchments (Kumar et al., 2005) and potentially alleviate the increased risk of flooding during the ASM when rainfall is most persistent and rivers are already at their peak flow. South Asia, even in the current climate, is particularly susceptible to flooding due to the high temporal and spatial variability of rainfall of the region. It is estimated that approximately $20 \%$ of Bangladesh floods annually (Mirza, 2002). Several studies have highlighted increases in both the extremes (Sharma, 2012; Rajeevan et al., 2008; Goswami et al., 2006; Joshi and Rajeevan, 2006) and the variability (Gupta et al., 2005) of precipitation in recent years that cause extreme rainfall events resulting in catastrophic levels of river flooding. Over 30 million people in India alone are affected by floods and more than 1500 lives are lost each year (Gupta et al., 2003), the economic cost of flooding is also considerable with the cumulative flood related losses estimated to be of the order of USD 16 billion between 1978 and 2006 (Singh and Kumar, 2013).

The timing of the peak flows of major rivers in this region is also very important in terms of flooding. In 1998 the peak flows of the Ganges and the Brahmaputra rivers occurred within 2 days of each other resulting in devastating flooding across the entire central region of Bangladesh. Approximately $70 \%$ of the country was inundated, the flood waters then remained above danger levels for more than 60 days (Mirza, 2002). This event caused extensive loss of life and livelihood in terms of damaged crops, fisheries and property and the slow recedence of flood waters hindered the relief operations and recovery in the region. This analysis does not suggest any change to the timing of the peak flows, only the magnitude. However, given the high probability of two rivers in this region having coincident peak flows in any given year (Mirza, 2002) and the likelihood that severe flooding will result, an increase in the magnitude of the peak could still be 
significant. Flooding can have a large impact on crops, for example in Bangladesh over $30 \%$ of the total flood related damages are due to the loss of crops. The estimated crop damage from the 1998 floods was estimated to be 3 million $\mathrm{t}$ (Gain et al., 2013). The slow receding of flood water can also mean the ground is not in a suitable condition to sow the next crop, restricting the growing time and potentially affecting crop yields for the following year. On the other hand a limited amount of flooding could also be a benefit, particularly for rice crops. Inundation of clear water can benefit crop yield, due to the fertilization effect of nitrogen producing blue-green algae in the water (Mirza et al., 2003).

In our simulations the reduced occurrence of the lowest flows could translate into an increase in the surface water resource in this region especially during periods when the river flows are traditionally very low. This could mean that the current and increasing pressure on groundwater (Rodell et al., 2009) may be alleviated in future years. Alternatively increases in the lowest flows may enable adaptation to a changing climate and the modification of irrigation practises. Current projections of future climate suggest that temperatures could also increase for this region (Cruz et al., 2007). Increasing temperatures poses a threat to crop yields of a different kind because this is a region where temperatures are already at a physiological maxima for some crops (Gornall et al., 2010). Rice yield, for example, is adversely affected by temperatures above $35^{\circ} \mathrm{C}$ at the critical flowering stage of its development (Yoshida, 1981). Wheat yields could also be affected by rising temperatures, with estimated losses of 45 million t per degree of temperature rise through the growing period (Aggarwal et al., 2012). Additional water resources for irrigation at previously low flow times of the year could allow sowing to take place at a different time of the year in order to avoid the highest temperatures, thereby reducing the likelihood of crop failure. However, with increasing variability and extremes, a potential feature of the future climate for this region (Hijioka et al., 2014), there is also the increased risk of longer periods with below average rainfall and potentially more incidences of drought. This could lead to additional demand for water for irrigation to prevent crops becoming water stressed (Aggarwal et al., 2012). There may also be increases in demand from other sources other than agriculture, for example the increasing population (United Nations, 2013) or the reduced availability of groundwater of an acceptable quality for domestic use (Gregory et al., 2005). Any of these factors, either individually or combined, could effectively cancel out any or all increases in resource from increased river flow due to climate change.

In addition there are a number of processes missing from the models used for these simulations that could change the sign of the projected changes. There is no irrigation included in these simulations, which could be important particularly on the basin scale. The impacts of extensive irrigation on the atmosphere are complex but could have a positive impact on water availability (Harding et al., 2013) due to evapora- tion and water being recycled within the basin. Tuinenburg et al. (2014) estimated that up to $35 \%$ of additional evaporation is recycled within the Ganges basin. Therefore, this aspect of the regional water cycle is not accounted for in these simulations. There is also no representation of glaciers that could act to increase or reduce river flows depending on the occurrence of negative or positive mass balance, respectively. In these simulations snowmelt is represented; however, representing glacial processes as snowmelt could act to enhance the seasonal cycle in the simulated river flows for both present-day and future projections as snow melts more readily than ice. These simulations also do not explicitly include groundwater, primarily focussing on river flows. Groundwater is a highly exploited part of water resources for South Asia. Representation of this would give a more complete picture of the total water resources for this region.

\section{Conclusions}

We present the first $25 \mathrm{~km}$ resolution regional climate projections of river flow for the South Asia region. A subselection of the HNRCMs are used to provide runoff to a river-routing model in order to provide river-flow rate, which can be compared directly with ERAInt and any available river gauge data for the South Asia region. This analysis focusses on the major South Asia river basins that originate in the glaciated Hindu-Kush Karakoram Himalayas: the Ganges-Brahmaputra and the Indus. The aim of this analysis is firstly to understand the river flows in the ECHAM5 and HadCM3 simulations and secondly examine how useful they are for understanding the changes in water resources for South Asia. We also consider what the projected changes in river flow to the $2100 \mathrm{~s}$ might mean for water resources across the Himalaya region.

The driving GCMs (ECHAM5 and HadCM3) have previously been shown to capture a range of temperatures and variability in precipitation similar to the AR4 ensemble for the much larger domain of Asia (Christensen et al., 2007). However, using just two ensemble members cannot capture the full range of these larger ensembles. In this analysis the seasonal cycle of precipitation, a key influence on river flows, is captured reasonably well for the downscaled GCMs compared to both observations and the downscaled ERAint simulation. Although observed precipitation is lower than in the model the underestimation inherent in precipitation observations at higher elevations is likely to be an important factor for this analysis, which includes the high Himalayas.

A number of GRDC gauge stations (GRDC, 2014), selected to capture the range of conditions across the Himalayan arc and sample the major river basins, provide observations of river flow for comparison against the HNRCM simulations. The lack of recent river flow data limited the gauges that could be selected for analysis. In the absence of robust observations we use a downscaled ERAint simulation 
in addition to the available observations to provide a useful benchmark against which to compare the downscaled GCM simulations. In general there is a tendency for overestimation of river-flow rate across the selected gauges compared with GRDC observations; however, comparison against the ERAint simulation is more mixed with some gauges showing higher and others with lower river flows than ERAInt. In general most of the simulations broadly agree with observations and ERAint to within the range of natural variability (of 1.5 SD) and agree on the periods of the highest and lowest river flow. Therefore, indicating that the RCM is able to capture the main features of both the climate and hydrology of this region for the present day.

The future projections indicate an increase in surface water resources, with river-flow rates at some of the gauges almost doubled by the end of the century. These increases in river flow occur for the gauges in the Ganges-Brahmaputra basin, which also shows an increasing trend in both evaporation and precipitation. Therefore, the changes in river flow are likely to be mainly driven by precipitation on the annual scale which more than counters the evaporation caused by increasing temperatures in the model. This is consistent with other analyses of precipitation that also use the A1B climate scenario (Nepal and Shrestha, 2015), which is a useful result. The trajectories of the annual average river flow, evaporation and precipitation for the Indus are much flatter, showing little or no trend.

The increases in the annual mean river flows are reflected in the seasonal cycles of river flow for the two future periods (2050s and 2080s), which indicate that most of the changes occur during peak flow periods. Some of the gauges toward the middle of the Himalayan arc, show changes above the range of present-day natural variability. This could be due to the increasing influence of the ASM and reducing influence of western disturbances from west to east having an additive effect. The gauges located furthest west and east in this analysis lie within the present-day natural variability. There were also differences between the two simulations across the Himalayan arc with HadCM3 suggesting increases in river flow at the upper end of the distribution for western gauges that was not evident in ECHAM5. The analysis shown here does not suggest a systematic change in the models for the timing of the maximum and minimum river flows relative to the present day, suggesting an over all increase in water resources at the top and bottom of the distribution. This has positive and negative implications with potentially more resources during usually water scarce periods. However, there are also implications in terms of increased future flood risk during periods where the river flow is particularly high. Increases in maximum flows for rivers in this region could be important in terms of loss of life, livelihoods, particularly agriculture and damage to infrastructure.

While this analysis suggests increasing surface water resources due to climate change, there are a number of other factors that could affect this result, both in terms of this analysis and uncertainties surrounding the region itself. The South Asia region is changing rapidly; therefore, other factors could have a large effect on water resources for this region. A rising population, expansion of industry (other than agriculture) and the continued depletion of groundwater could change the demand for surface water resource from other parts of the South Asia economy. In addition increasing variability of an already changeable climate could lead to extended periods throughout the year of rainfall below the annual average, leading to an increase in demand for irrigation resource. In terms of this analysis, this is only one RCM and another RCM could produce a different result. Also there are missing hydrological processes in the RCM and river-flow model that could impact the river flows directly. The RCM and river-flow model do not include abstraction and irrigation, groundwater recharge or explicitly include glacial processes and their contribution to river flow. Including glacial processes in the form of a glacier model together with river routing within the land-surface representation will be useful to establish if the contribution from glaciers changes the timing and/or magnitude of both the lowest and highest flows in these gauges. Likewise including representation of water extraction (both from rivers and groundwater) particularly for irrigation, the biggest user of water in the region, will help to provide a more complete picture of the demand for water resources for the South Asia region. Including irrigation and therefore the associated evaporation will capture part of the water cycle not possible with the current model and maintain the regional water balance. Including representation of these processes in the RCM or river-flow model would improve the robustness of the future projections of water resources and further our understanding of the water balance for this region. These processes could have a large impact on the water balance in the model potentially changing the signal of the projected changes in river flow. Understanding the interactions between availability of water resources, irrigation and food production for this region by using a more integrated approach, such as that used in Biemans et al. (2013), may also help with understanding how pressures on resources could change with time. In support of this work and others, there is also a need for good-quality observations of both precipitation and river flow available for long enough time periods to conduct robust water resource assessments for this region.

Acknowledgements. The research leading to these results has received funding from the European Union Seventh Framework Programme FP7/2007-2013 under grant agreement no. 603864. Camilla Mathison, Pete Falloon and Andy Wiltshire were supported by the Joint UK DECC/Defra Met Office Hadley Centre Climate Programme (GA01101). Thanks to Neil Kaye for his GIS expertise.

Edited by: B. Schaefli 


\section{References}

Aggarwal, P., Talukdar, K., and Mall, R.: Potential yields of ricewheat system in the Indo-Gangetic plains of India, Rice-Wheat consortium for the Indo-Gangetic plains, New Delhi, India, 16 pp., 2000.

Aggarwal, P., Palanisami, K., Khanna, M., and Kakumanu, K.: Climate change and food security of India: adaptation strategies for the irrigation sector, World Agriculture, 3, 20-26, 2012.

Akhtar, M., Ahmad, N., and Booij, M.: The impact of climate change on the water resources of Hindukush-KarakorumHimalaya region under different glacier coverage scenarios, J. Hydrol., 355, 148-163, doi:10.1016/j.jhydrol.2008.03.015, 2008.

Andermann, C., Bonnet, S., and Gloaguen, R.: Evaluation of precipitation data sets along the Himalayan front, Geochem. Geophy. Geosy., 12, Q07023, doi:10.1029/2011GC003513, 2011.

Annamalai, H., Hamilton, K., and Sperber, K.: The South Asian summer monsoon and its relationship with ENSO in the IPCC AR4 simulations, J. Climate, 20, 1071-1092, doi:10.1175/JCLI4035.1, 2007.

Arnold, J. G., Srinivasan, R., Muttiah, R. S., and Williams, J. R.: Large area hydrologic modeling and assessment Part I: Model development, J. Am. Water Resour. Assoc., 34, 73-89, doi:10.1111/j.1752-1688.1998.tb05961.x, 1998.

Arthington, A. H., Bunn, S. E., Poff, N. L., and Naiman, R. J.: The challenge of providing environmental flow rules to sustain river ecosystems, Ecol. Appl., 16, 1311-1318, doi:10.1890/10510761(2006)016[1311:TCOPEF]2.0.CO;2, 2006.

Bajracharya, S. and Shrestha, B.: The Status of Glaciers in the Hindu Kush-Himalayan Region, ICIMOD, Kathmandu, http:// lib.icimod.org/record/9419, last access: July 2015, 2011.

Barnett, T., Adam, J., and Lettenmaier, D.: Potential impacts of a warming climate on water availability in snow-dominated regions, Nature, 438, 303-309, doi:10.1038/nature04141, 2005.

Biemans, H., Speelman, L., Ludwig, F., Moors, E., Wiltshire, A., Kumar, P., Gerten, D., and Kabat, P.: Future water resources for food production in five South Asian river basins and potential for adaptation - A modeling study, Sci. Total Environ., 468-469, Supplement, S117-S131, doi:10.1016/j.scitotenv.2013.05.092, 2013.

Bolch, T., Kulkarni, A., Kääb, Huggel, C., Paul, F., Cogley, J. G., Frey, H., Kargel, J. S., Fujita, K., Scheel, M., Bajracharya, S., and Stoffel, M.: The State and Fate of Himalayan Glaciers, Science, 336, 310-314, doi:10.1126/science.1215828, 2012.

Christensen, J., Hewitson, B., Busuioc, A., Chen, A., Gao, X., Held, I., Jones, R., Kolli, R., Kwon, W.-T., Laprise, R., na Rueda, V. M., Mearns, L., Meneńdez, C., Räisänen, J., Rinke, A., Sarr, A., and Whetton, P.: Regional Climate Projections, in: Climate Change 2007: The Physical Science Basis, Contribution of Working Group I, Fourth Assessment Report of the Intergovernmental Panel on Climate Change, https:// www.ipcc.ch/publications_and_data/ar4/wg1/en/ch11.html, last access: September 2015, 2007.

Clark, D. B. and Gedney, N.: Representing the effects of subgrid variability of soil moisture on runoff generation in a land surface model, J. Geophys. Res., 113, D10111, doi:10.1029/2007JD008940, 2008.

Collins, D. N., Davenport, J. L., and Stoffel, M.: Climatic variation and runoff from partially-glacierised Himalayan tributary basins of the Ganges, Sci. Total Environ., 468-469, Supplement S48S59, doi:10.1016/j.scitotenv.2013.10.126, 2013.

Cruz, R., Harasawa, H., Lal, M., Wu, S., Anokhin, Y., Punsalmaa, B., Honda, Y., Jafari, M., Li, C., and Huu Ninh, N.: Asia, in: Climate Change 2007: Impacts, Adaptation and Vulnerability, Contribution of Working Group II, Fourth Assessment Report of the Intergovernmental Panel on Climate Change, 469-506, https:// www.ipcc.ch/publications_and_data/ar4/wg2/en/ch10.html, last access: June 2015, 2007.

Dankers, R., Christensen, O. B., Feyen, L., Kalas, M., and de Roo, A.: Evaluation of very high-resolution climate model data for simulating flood hazards in the Upper Danube Basin, J. Hydrol. 347, 319-331, doi:10.1016/j.jhydrol.2007.09.055, 2007.

Dee, D. P., Uppala, S. M., Simmons, A. J., Berrisford, P., Poli, P., Kobayashi, S., Andrae, U., Balmaseda, M. A., P., G. B., Bauer, Bechtold, P., Beljaars, A. C. M., van de Berg, L., Bidlot, J., Bormann, N., Delsol, C., Dragani, R., Fuentes, M., Geer, A. J., Haimberger, L., Healy, S. B., Hersbach, H., Hólm, E. V., Isaksen, L., Kållberg, P., Köhler, M., Matricardi, M., McNally, A. P., Monge-Sanz, B. M., Morcrette, J.-J., Park, B.-K., Peubey, C., de Rosnay, P., Tavolato, C., Thépaut, J.-N., and Vitart, F.: The ERA-Interim reanalysis: configuration and performance of the data assimilation system, Q. J. Roy. Meteorol. Soc., 137, 553597, doi:10.1002/qj.828, 2011.

Dhar, O. and Nandargi, S.: A study of floods in the Brahmaputra basin in India, Int. J. Climatol., 20, 771-781, doi:10.1002/10970088(20000615)20:7<771::AID-JOC518>3.0.CO;2-Z, 2000.

Dimri, A., Yasunari, T., Wiltshire, A., Kumar, P., Mathison, C., Ridley, J., and Jacob, D.: Application of regional climate models to the Indian winter monsoon over the western Himalayas, Sci. Total Environ., 468, S36-S47, 2013.

Dolman, A. J. and Gregory, D.: The Parametrization of Rainfall Interception In GCMs, Q. J. Roy. Meteorol. Soc., 118, 455-467, doi:10.1002/qj.49711850504, 1992.

Essery, R. L. H., Best, M. J., and Cox, P. M.: MOSES 2.2 technical documentation, Hadley Centre Technical Note, http://www. metoffice.gov.uk/archive/hadley-centre-technical-note-30, last access: May 2015, 2001

Essery, R. L. H., Best, M. J., Betts, R. A., Cox, P. M., and Taylor, C.: Explicit Representation of Subgrid Heterogeneity in a GCM Land Surface Scheme, J. Hydrometeorol., 4, 530-543, doi:10.1175/1525-7541(2003)004<0530:EROSHI>2.0.CO;2, 2003.

Falloon, P., Betts, R., and Bunton, C.: New global river routing scheme in the unified model, Hadley Centre Technical Note, http://www.metoffice.gov.uk/archive/ hadley-centre-technical-note-72, last access: July 2015, 2007.

Falloon, P., Betts, R. A., Wiltshire, A., Dankers, R., Mathison, C., McNeall, D., Bates, P., and Trigg, M.: Validation of river flows in hadgem 1 and hadcm 3 with the trip river flow model, J. Hydrometeorol., 12, 1157-1180, doi:10.1175/2011JHM1388.1, 2011.

Fekete, B. M., Vörösmarty, C. J., and Lammers, R. B.: Scaling gridded river networks for macroscale hydrology: Development, analysis, and control of error, Water Resour. Res., 37, 19551967, doi:10.1029/2001WR900024, 2001.

Fujita, K. and Nuimura, T.: Spatially heterogeneous wastage of Himalayan glaciers, P. Natl. Acad. Sci., 108, 14011-14014, 2011.

Gain, A. K., Apel, H., Renaud, F. G., and Giupponi, C.: Thresholds of hydrologic flow regime of a river and investigation of climate 
change impact the case of the Lower Brahmaputra river Basin, Climatic Change, 120, 463-475, doi:10.1007/s10584-013-0800$\mathrm{x}, 2013$.

Gardelle, J., Berthier, E., Arnaud, Y., and Kääb, A.: Region-wide glacier mass balances over the Pamir-Karakoram-Himalaya during 1999-2011, The Cryosphere, 7, 1263-1286, doi:10.5194/tc7-1263-2013, 2013.

Gedney, N. and Cox, P.: The Sensitivity of Global Climate Model Simulations to the Representation of Soil Moisture Heterogeneity, J. Hydrometeorol., 4, 1265-1275, doi:10.1175/15257541(2003)004<1265:TSOGCM>2.0.CO;2, 2003.

Gordon, C., Cooper, C., Senior, C. A., Banks, H., Gregory, J. M., Johns, T. C., Mitchell, J. F. B., and Wood, R. A.: The simulation of SST, sea ice extents and ocean heat transports in a version of the Hadley Centre coupled model without flux adjustments, Clim. Dynam., 16, 147-168, doi:10.1007/s003820050010, 2000.

Gornall, J., Betts, R., Burke, E., Clark, R., Camp, J., Willett, K., and Wiltshire, A.: Implications of climate change for agricultural productivity in the early twenty-first century, Philos. T. Roy. Soc. B, 365, 2973-2989, doi:10.1098/rstb.2010.0158, 2010.

Gosain, A. K., Rao, S., and Basuray, D.: Climate change impact assessment on hydrology of Indian river basins, Current Science, 90, 346-353, 2006.

Goswami, B. N. and Xavier, P. K.: Dynamics of "internal" interannual variability of the Indian summer monsoon in a GCM, J. Geophys. Res., 110, D24104, doi:10.1029/2005JD006042, 2005.

Goswami, B. N., Venugopal, V., Sengupta, D., Madhusoodanan, M. S., and Xavier, P. K.: Increasing Trend of Extreme Rain Events Over India in a Warming Environment, Science, 314, 1442-1445, doi:10.1126/science.1132027, 2006.

GRDC: The Global Runoff Data Centre, Koblenz, Germany, 2014.

Gregory, P., Ingram, J., and Brklacich, M.: Climate change and food security, Philos. T. Roy. Soc. B, 360, 2139-2148, doi:10.1098/rstb.2005.1745, 2005.

Gupta, A. D., Babel, M. S., Albert, X., and Mark, O.: Water Sector of Bangladesh in the Context of Integrated Water Resources Management: A Review, Int. J. Water Resour. Develop., 21, 385398, doi:10.1080/07900620500037818, 2005.

Gupta, S. and Deshpande, D.: Water for India in 2050: first order assessment of available options, Current Science, 86, 1216-1224, 2004.

Gupta, S., Javed, A., and Datt, D.: Economics of Flood Protection in India, Nat. Hazards, 28, 199-210, 2003.

Harding, R., Blyth, E., Tuinenburg, O., and Wiltshire, A.: Land atmosphere feedbacks and their role in the water resources of the Ganges basin, Sci. Total Environ., 468-469, Supplement S85S92, doi:10.1016/j.scitotenv.2013.03.016, 2013.

Hijioka, Y., Lin, E., Pereira, J., Corlett, R., Cui, X., Insarov, G., Lasco, R., Lindgren, E., and Surjan, A.: Asia, in: Climate Change 2014: Impacts, Adaptation, and Vulnerability, Part B: Regional Aspects, Contribution of Working Group II, Fifth Assessment Report of the Intergovernmental Panel on Climate Change, Cambridge University Press, Cambridge, United Kingdom and New York, NY, USA, 1327-1370, 2014.

Hirabayashi, Y., Kanae, S., Emori, S., Oki, T., and Kimoto, M.: Global projections of changing risks of floods and droughts in a changing climate, Hydrolog. Sci. J., 53, 754-772, 2008.
Immerzeel, W. W., van Beek, L. P. H., and Bierkens, M. F. P.: Climate Change Will Affect the Asian Water Towers, Science, 328, 1382-1385, doi:10.1126/science.1183188, 2010.

Immerzeel, W. W., Wanders, N., Lutz, A. F., Shea, J. M., and Bierkens, M. F. P.: Reconciling high altitude precipitation in the upper Indus Basin with glacier mass balances and runoff, Hydrol. Earth Syst. Sci. Discuss., 12, 4755-4784, doi:10.5194/hessd-124755-2015, 2015.

Jacob, D., Bärring, L., Christensen, O. B., Christensen, J. H., de Castro, M., Déqué, M., Giorgi, F., Hagemann, S., Hirschi, M., Jones, R., Kjellström, E., Lenderink, G., Rockel, B., Sánchez, E., Schär, C., Seneviratne, S. I., Somot, S., van Ulden, A., and van den Hurk, B.: An inter-comparison of regional climate models for Europe: model performance in present-day climate, Climatic Change, 81, 31-52, doi:10.1007/s10584-006-9213-4, 2007.

Jhajharia, D., Dinpashoh, Y., Kahya, E., Singh, V. P., and FakheriFard, A.: Trends in reference evapotranspiration in the humid region of northeast India, Hydrol. Process., 26, 421-435, doi:10.1002/hyp.8140, 2012.

Johnston, R. and Smakhtin, V.: Hydrological Modeling of Large river Basins: How Much is Enough?, Water Resour. Manage., 28, 2695-2730, doi:10.1007/s11269-014-0637-8, 2014.

Jones, R. G., Noguer, M., Hassell, D. C., Hudson, D., Wilson, S. S., Jenkins, G. J., and Mitchell, J. F.: Generating high resolution climate change scenarios using PRECIS, Met Office Hadley Centre, Exeter, UK, http://www.metoffice.gov.uk/media/pdf/6/5/ PRECIS_Handbook.pdf, last access: August 2015, 2004.

Joshi, U. and Rajeevan, M.: Trends in precipitation extremes over India, National Climate Centre Research report, http://www. imdpune.gov.in/ncc_rept/RESEARCH_REPORT_3.pdf, last access: August 2015, 2006.

Kääb, A., Berthier, E., Nuth, C., Gardelle, J., and Arnaud, Y.: Contrasting patterns of early twenty-first-century glacier mass change in the Himalayas, Nature, 488, 495-498, doi:10.1038/nature11324, 2012.

Kapnick, S. B., Delworth, T. L., Ashfaq, M., Malyshev, S., and Milly, P. C. D.: Snowfall less sensitive to warming in Karakoram than in Himalayas due to a unique seasonal cycle, Nat. Geosci., 7, 834-840, doi:10.1038/ngeo2269, 2014.

Kaser, G., Großhauser, M., and Marzeion, B.: Contribution potential of glaciers to water availability in different climate regimes, P. Natl. Acad. Sci. USA, 107, 20223-20227, doi:10.1073/pnas.1008162107, 2010.

Kay, A. L., Reynard, N. S., and Jones, R. G.: RCM rainfall for UK flood frequency estimation. I. Method and validation, J. Hydrol., 318, 151-162, doi:10.1016/j.jhydrol.2005.06.012, 2006.

Kumar, P., Wiltshire, A., Mathison, C., Asharaf, S., Ahrens, B., Lucas-Picher, P., Christensen, J. H., Gobiet, A., Saeed, F., Hagemann, S., and Jacob, D.: Downscaled climate change projections with uncertainty assessment over India using a high resolution multi-model approach, Sci. Total Environ., 468-469, Supplement S18-S30, doi:10.1016/j.scitotenv.2013.01.051, 2013.

Kumar, R., Singh, R., and Sharma, K.: Water resources of India, Current Science, 89, 794-811, 2005.

Linsley, R., Kohler, M., and Paulhus, J.: Hydrology for Engineers, McGraw-Hill series in water resources and environmental engineering, McGraw-Hill, http://books.google.co.uk/books?id= 9vROAAAAMAAJ, last access: June 2015, 1982. 
Lucas-Picher, P., Christensen, J. H., Saeed, F., Kumar, P., Asharaf, S., Ahrens, B., Wiltshire, A. J., Jacob, D., and Hagemann, S.: Can Regional Climate Models Represent the Indian Monsoon?, J. Hydrometeorol., 12, 849-868, doi:10.1175/2011JHM1327.1, 2011.

Mathison, C., Wiltshire, A., Dimri, A., Falloon, P., Jacob, D., Kumar, P., Moors, E., Ridley, J., Siderius, C., Stoffel, M., and Yasunari, T.: Regional projections of North Indian climate for adaptation studies, Sci. Total Environ., 468-469, Supplement S4S17, doi:10.1016/j.scitotenv.2012.04.066, 2013.

McMillan, H., Freer, J., Pappenberger, F., Krueger, T., and Clark, M.: Impacts of uncertain river flow data on rainfall-runoff model calibration and discharge predictions, Hydrol. Process., 24, 1270-1284, 2010.

McVicar, T. R., Roderick, M. L., Donohue, R. J., Li, L. T., Niel, T. G. V., Thomas, A., Grieser, J., Jhajharia, D., Himri, Y., Mahowald, N. M., Mescherskaya, A. V., Kruger, A. C., Rehman, S., and Dinpashoh, Y.: Global review and synthesis of trends in observed terrestrial near-surface wind speeds: Implications for evaporation, J. Hydrol., 416-417, 182-205, doi:10.1016/j.jhydrol.2011.10.024, 2012.

Milly, P. C. D., Dunne, K. A., and Vechhia, A.: Global pattern of trends in streamflow and water availability in a changing climate, Nature, 438, 347-350, 2005.

Mirza, M. M. Q.: Global warming and changes in the probability of occurrence of floods in Bangladesh and implications, Global Environ. Change, 12, 127-138, doi:10.1016/S09593780(02)00002-X, 2002.

Mirza, M. M. Q., Warrick, R., Ericksen, N., and Kenny, G.: Trends and persistence in precipitation in the Ganges, Brahmaputra and Meghna river basins, Hydrolog. Sci. J., 43, 845-858, doi:10.1080/02626669809492182, 1998.

Mirza, M. M. Q., Warrick, R. A., and Ericksen, N. J.: The Implications of Climate Change on Floods of the Ganges, Brahmaputra and Meghna Rivers in Bangladesh, Climatic Change, 57, 287318, doi:10.1023/A:1022825915791, 2003.

Moors, E. J., Groot, A., Biemans, H., van Scheltinga, C. T., Siderius, C., Stoffel, M., Huggel, C., Wiltshire, A., Mathison, C., Ridley, J., Jacob, D., Kumar, P., Bhadwal, S., Gosain, A., and Collins, D. N.: Adaptation to changing water resources in the Ganges basin, northern India, Environ. Sci. Policy, 14, 758-769, doi:10.1016/j.envsci.2011.03.005, 2011.

Morse, A., Prentice, C., and T.Carter: Assessments of climate change impacts, Ensembles: Climate change and its impacts: Summary of research and results from the ENSEMBLES project, 107-129,http://ensembles-eu.metoffice.com/docs/Ensembles_ final_report_Nov09.pdf, last access: June 2015, 2009.

Murphy, J. M., Sexton, D. M. H., Barnett, D. N., Jones, G. S., Webb, M. J., Collins, M., and Stainforth, D. A.: Quantification of modelling uncertainties in a large ensemble of climate change simulations, Nature, 430, 768-772, doi:10.1038/nature02771, 2004.

Murphy, J. M., Sexton, D. M. H., Jenkins, G. J., Boorman, P. M., Booth, B. B. B., Brown, C. C., Clark, R. T., Collins, M., Harris, G. R., Kendon, E. J., Betts, R. A., Brown, S. J., Howard, T. P., Humphrey, K. A., McCarthy, M. P., McDonald, R. E., Stephens, A., Wallace, C., Warren, R., Wilby, R., and Wood, R. A.: UK Climate Projections Science Report: Climate change projections., Met Office Hadley Centre, 124-131, http://ukclimateprojections.metoffice.gov.uk/ media.jsp?mediaid $=87894 \&$ filetype $=$ pdf, last access: August 2015, 2009.

Nakicenovic, N., Alcamo, J., Grubler, A., Riahi, K., Roehrl, R., Rogner, H.-H., and Victor, N.: Special Report on Emissions Scenarios (SRES), A Special Report of Working Group III of the Intergovernmental Panel on Climate Change, http://www.ipcc.ch/ ipccreports/sres/emission/index.php?idp=0 (last access: September 2015), 2000.

Nepal, S. and Shrestha, A. B.: Impact of climate change on the hydrological regime of the Indus, Ganges and Brahmaputra river basins: a review of the literature, Int. J. Water Resour. Develop., 31, 201-218, doi:10.1080/07900627.2015.1030494, 2015.

Nohara, D., Kitoh, A., Hosaka, M., and Oki, T.: Impact of Climate Change on River Discharge Projected by Multimodel Ensemble, J. Hydrometeorol., 7, 1076-1089, doi:10.1175/JHM531.1, 2006.

Nyeko, M.: Hydrologic Modelling of Data Scarce Basin with SWAT Model: Capabilities and Limitations, Water Resour. Manage., 29, 81-94, doi:10.1007/s11269-014-0828-3, 2015.

Oki, T. and Sud, Y. C.: Design of Total Runoff Integrating Pathways (TRIP), A Global River Channel Network, Earth Interact., 2, 1-37, doi:10.1175/10873562(1998)002<0001:DOTRIP>2.3.CO;2, 1998.

Oki, T., Nishimura, T., and Dirmeyer, P.: Assessment of annual runoff from land surface models using Total Runoff Integrating Pathways (TRIP), J. Meteorol. Soc. Jpn. Ser. II, 77, 235-255, doi:10.1080/02626668509490989, 1999.

Pope, V., Gallani, M. L., Rowntree, P. R., and Stratton, R. A.: The impact of new physical parametrizations in the Hadley Centre climate model: HadAM3, Clim. Dynam., 16, 123-146, doi:10.1007/s003820050009, 2000.

Rajeevan, M., Bhate, J., and Jaswal, K. A.: Analysis of variability and trends of extreme rainfall events over India using 104 years of gridded daily rainfall data, Geophys. Res. Lett., 35, L18707, doi:10.1029/2008GL035143, 2008.

Ridley, J., Wiltshire, A., and Mathison, C.: More frequent occurrence of westerly disturbances in Karakoram up to 2100, Sci. Total Environ., 468-469, Supplement S31-S35, doi:10.1016/j.scitotenv.2013.03.074, 2013.

Rodell, M., Velicogna, I., and Famiglietti, J.: Satellite-based estimates of groundwater depletion in India, Nature, 460, 999-1002, doi:10.1038/nature08238, 2009.

Roeckner, E., Bäuml, G., Bonaventura, L., Brokopf, R., Esch, M., Giorgetta, M., Hagemann, S., Kirchner, I., Kornblueh, L., Manzini, E., Rhodin, A., Schlese, U., Schulzweida, U., and Tompkins, A.: The atmospheric general circulation model ECHAM 5, PART I: Model description, Max Planck Institute for Meteorology Rep. 349, http://www.mpimet.mpg.de/fileadmin/ publikationen/Reports/max_scirep_349.pdf, last access: June 2015, 2003.

Sampson, C. C., Fewtrell, T., O’Loughlin, F., Pappenberger, F., Bates, P. B., Freer, J. E., and Cloke, H. L.: The impact of uncertain precipitation data on insurance loss estimates using a flood catastrophe model, Hydrol. Earth Syst. Sci., 18, 23052324, doi:10.5194/hess-18-2305-2014, 2014.

Sarkar, U. K., K.Pathak, A., Sinha, R. K., Sivakumar, K., Pandian, A. K., Pandey, A., Dubey, V. K., and Lakra, W. S.: Freshwater fish biodiversity in the River Ganga (India): changing pattern, threats and conservation perspectives, Rev. Fish Biol. Fisher., 22, 251-272, doi:10.1007/s11160-011-9218-6, 2012. 
Scherler, D., Bookhagen, B., and Strecker, M.: Spatially variable response of Himalayan glaciers to climate change affected by debris cover, Nat. Geosci., 4, 156-159, doi:10.1038/ngeo1068, 2011.

Scott, D.: Multivariate density estimation: theory, practice, and visualization, in: vol. 383, John Wiley \& Sons, New Jersey and Canada, 2009.

Seidel, K., Martinec, J., and Baumgartner, M. F.: Modelling runoff and impact of climate change in large Himalayan basins, in: International Conference on Integrated Water Resources Management (ICIWRM), Citeseer, 19-21, 2000.

Sharma, D.: Situation analysis of flood disaster in south and southeast Asia - a need of integrated approach, Int. J. Sci. Environ. Technol., 1, 167-173, 2012.

Shrestha, A. B. and Aryal, R.: Climate change in Nepal and its impact on Himalayan glaciers, Reg. Environ. Change, 11, 65-77, doi:10.1007/s10113-010-0174-9, 2011.

Silverman, B.: Density Estimation for Statistics and Data Analysis, in: Monographs on Statistics and Applied Probability, Chapman and Hall, London, Chapter 1 and 2, 1-176, 1986.

Simmons, A., Uppala, S., Dee, D., and Kobayashi, S.: ERA-Interim: New ECMWF reanalysis products from 1989 onwards, ECMWF Newsletter, 110, 25-35, 2007.

Singh, O. and Kumar, M.: Flood events, fatalities and damages in India from 1978 to 2006, Nat. Hazards, 69, 1815-1834, 2013.

Singh, P. and Bengtsson, L.: Impact of warmer climate on melt and evaporation for the rainfed, snowfed and glacierfed basins in the Himalayan region, J. Hydrol., 300, 140-154, doi:10.1016/j.jhydrol.2004.06.005, 2005.

Singh, P. and Kumar, N.: Impact assessment of climate change on the hydrological response of a snow and glacier melt runoff dominated Himalayan river, J. Hydrol., 193, 316-350, doi:10.1016/S0022-1694(96)03142-3, 1997.

Singh, P., Haritashya, U. K., and Kumar, N.: Modelling and estimation of different components of streamflow for Gangotri Glacier basin, Himalayas, Hydrolog. Sci. J., 53, 309-322, doi:10.1623/hysj.53.2.309, 2008.

Smakhtin, V. and Anputhas, M.: An assessment of environmental flow requirements of Indian river basins, IWMI Research Report 107, http://www.iwmi.cgiar.org/Publications/ IWMI_Research_Reports/PDF/PUB107/RR107.pdf, last access: May 2015, 2006.

Smakhtin, V. U., Shilpakar, R. L., and Hughes, D. A.: Hydrology-based assessment of environmental flows: an example from Nepal, Hydrolog. Sci. J., 51, 207-222, doi:10.1623/hysj.51.2.207, 2006.

Thenkabail, P. S., Schull, M., and Turral, H.: Ganges and Indus river basin land use/land cover LULC) and irrigated area mapping using continuous streams of MODIS data, Remote Sens. Environ., 95, 317-341, doi:10.1016/j.rse.2004.12.018, 2005.
Tuinenburg, O. A., Hutjes, R. W. A., Stacke, T., Wiltshire, A., and Lucas-Picher, P.: Effects of irrigation in india on the atmospheric water budget, J. Hydrometeorol., 15, 1028-1050, doi:10.1175/JHM-D-13-078.1, 2014.

United Nations: Fertility Levels and Trends as Assessed in the 2012 Revision of World Population Prospects, Department of Economic and Social Affairs, Population Division, http://esa.un.org/ unpd/wpp/index.htm, last access: May 2015, 2013.

Vörösmarty, C., Fekete, B., Meybeck, M., and Lammers, R.: Geomorphometric attributes of the global system of rivers at 30-minute spatial resolution, J. Hydrol., 237, 17-39, doi:10.1016/S0022-1694(00)00282-1, 2000a.

Vörösmarty, C., Fekete, B., Meybeck, M., and Lammers, R.: Global system of rivers: Its role in organizing continental land mass and defining land-to-ocean linkages, Global Biogeochem. Cy., 14, 599-621, doi:10.1029/1999GB900092, 2000b.

Vörösmarty, C. J., McIntyre, P. B., Gessner, M. O., Dudgeon, D., Prusevich, A., Green, P., Glidden, S., Bunn, S. E., Sullivan, C. A., Liermann, C. R., and Davies, P. M.: Global threats to human water security and river biodiversity, Nature, 467, 555-561, doi:10.1038/nature09440, 2010.

Wescoat Jr., J.: Managing the Indus River basin in light of climate change: Four conceptual approaches, Global Environ. Change, 1, 381-395, doi:10.1016/0959-3780(91)90004-D, 1991.

Wiltshire, A. J.: Climate change implications for the glaciers of the Hindu Kush, Karakoram and Himalayan region, The Cryosphere, 8, 941-958, doi:10.5194/tc-8-941-2014, 2014.

Wiltshire, A. J., Gornall, J., Booth, B., Dennis, E., Falloon, P., Kay, G., McNeall, D., McSweeney, C., and Betts, R.: The importance of population, climate change and $\left\{\mathrm{CO}_{2}\right\}$ plant physiological forcing in determining future global water stress, Global Environ. Change, 23, 1083-1097, doi:10.1016/j.gloenvcha.2013.06.005, 2013a.

Wiltshire, A. J., Kay, G., Gornall, J. L., and Betts, R. A.: The Impact of Climate, $\left\{\mathrm{CO}_{2}\right\}$ and Population on Regional Food and Water Resources in the 2050s, Sustainability, 5, 2129-2151, doi:10.3390/su5052129, 2013b.

Yatagai, A., Kamiguchi, K., Arakawa, O., Hamada, A., Yasutomi, N., and Kitoh, A.: Aphrodite: constructing a long-term daily gridded precipitation dataset for asia based on a dense network of rain gauges, B. Am. Meteorol. Soc., 93, 1401-1415, doi:10.1175/BAMS-D-11-00122.1, 2012.

Yoshida, S.: Fundamentals of rice crop science, Manila, Philipines, http://books.irri.org/9711040522_content.pdf, last access: May 2015, 1981. 